HYPOTHESIS

\title{
ANENCEPHALY AND SPINA BIFIDA ARE USUALLY PREVENTABLE BY AVOIDANCE OF A SPECIFIC BUT UNIDENTIFIED SUBSTANCE PRESENT IN CERTAIN POTATO TUBERS
}

\author{
J. H. RENWICK \\ Department of Public Health, London School of Hygiene and Tropical Medicine
}

\section{INTRODUCTION}

Occupational class, geography, sex, maternal age, year, and season of the year are some of the epidemiological factors that are known to affect incidence rates of anencephaly and spina bifida cystica. There is great similarity between the epidemiological associations established for anencephaly and those established for spina bifida cystica and there is mutual predisposition to occurrence of the other within sibships (Record and McKeown, 1950a). It would probably be generally agreed that the two abnormalities would be likely also to respond about equally to most manipulations of the environment for the purpose of prevention. To simplify the presentation of an hypothesis, these known similarities and expected similarities are exaggerated in most of what follows to the point of pretended identity between the two conditions. This false entity is denoted by the initials ASB. Anencephaly is almost as frequent as spina bifida among total births (live and still). When an incidence rate is available for only one, an approximately equivalent rate of ASB per thousand total births is obtained by doubling it and is used here.

A remarkable pattern of ASB epidemiology is emerging. The pattern appears to have sufficient richness of shape and detail to allow an assessment of many of the aetiological hypotheses that have been conceived and to make most of them implausible.

The process whereby we light upon a tenable hypothesis that is compatible with a detailed epidemiological pattern is an elaborately complex one of trial and error embellished here and there with small patches of deductive reasoning. It is usually quite impracticable to present a fair summary of the steps involved in the process, which is to a considerable extent a partly subconscious one of fitting. I shall therefore choose the most promising group of hypotheses and try only to show that the group is worth testing. I shall alșo make the perhaps hasty assumption that the cotton-eared marmoset (Callithrix jacchus), whose response to the teratogenic influence of thalidomide closely simulates that of man (Poswillo, 1972), and which has also a remarkably similar timing of early embryogenesis, will sometimes manifest ASB when exposed to conditions similar to those that produce ASB in man, whatever those conditions may be. If this assumption turns out to be false, work might be undertaken in marmosets that might prove fruitless, but if it is true a complete resolution should soon be possible to the most fascinating and at the same time most serious conundrum of applied developmental pathology. Anencephaly has occurred spontaneously in Macaca fascicularis (Price and Gilles, 1971), Macaca arctoides (Christie, 1969), and in other primates (Schultz, 1956). The teratogenic insult must occur before the fourth week of gestation since anencephaly and spina bifida were both found in one human embryo of only $2.1 \mathrm{~mm}$ length (Mall, 1917). Giroud (1960) reviews the teratology of anencephaly. The marmoset's suitability (Poswillo, 1972) depends on the above-mentioned similarity to man of its early embryological development, and on its response to radiation and chemical teratogenic agents. It presents a degree of financial feasibility not offered by many other primates: the space requirement, for example, is only one eighth of that of, say, a Rhesus monkey.

\section{HYPOTHESES}

The greater incidence of anencephaly among winter births, noted by McKeown and Record (1951), suggested that the risk of the malformation was higher for infants conceived in the spring and summer than for those conceived in the autumn and winter. Record (1961) showed that in Scotland the risk of teratogenesis was maximal from March to July and followed a pattern closely resembling that for the number of hoưrs of daylight. Leçk and Reçord 
(1966) suggested that this was more in accord with a dietary explanation than an infective one, and later (unpublished) suggested that the responsible food could be the potato which might become teratogenic as it aged, particularly if exposed to light. Glycosides of the steroid solanidine (i.e., the solanines and chaconines) develop in and under the skin of the potato tuber on storage (Gull and Isenberg, $1960)$ and on exposure to ultraviolet light. These substances have fungicidal and nematocidal properties but their teratogenicity has not yet been established.

I have recently learned that Dr. A. J. P. Martin (unpublished) conceived of the potato's being responsible. He found one of its pathogens, Synchytrium endobioticum, the fungus responsible for potato wart disease, to have a geographical distribution similar to that of ASB. This correlation, he appreciated, must be indirect because wart disease has been brought under control without the appearance of a correlated control of ASB incidence. Further, wart was not known in the UK until 1896. A regional factor, perhaps climatic, was therefore believed to be operating that favoured the wart fungus and also affected the potato in such a way as to render it a hazard to human fetuses.

A number of recent publications can be used to support a role for antibiotic compounds in potatoes. Yet a good case can also be made for the involvement of fungi, in that ASB and potato blight fungus Phytophthora infestans seem to affect the same areas of the world and to a concordant degree. This correlation has not been noted before. Perhaps the apparent conflict between these hypotheses can be resolved by the hypothesis that it is some antifungal product of the potato that induces ASB and that its concentration is correlated with the severity of the attack of the blight fungus. Thus the tendency for bad blight areas to be bad ASB areas perhaps reflects the fact that the potatoes that survive to be handled and eaten in such areas are those that genetically or otherwise have a high level of antifungal compounds - compounds of which at least one happens to be teratogenic in man. This is the general form of the hypothesis. The precise chemical is not yet known nor its route of entry. Though it is not the one actually favoured, the percutaneous route of entry during potato peeling is chosen in discussing the goodness of fit to a variety of epidemiological data, and other routes are largely left to a final section of the paper. But first it will be helpful to refer to some relevant features of plant physiology and pathology that may impinge on the argument. For these aspects, the books of Cox and Large (1960) and Burton (1966) are of great value.
Pathological and Chemical Changes in the Potato

\section{PhytophthoRA INFESTANS}

The pathogenic races of the blight fungus Phyto phthora infestans seem to have evolved in Mexico? but apparently did not survive the long sea voyage in sailing ships across the Atlantic. They first reached Ireland, presumably by a steamship, in about 1840 (and led to the disastrous famines of 1845-50). They reached North America at about theo same time. In the present century, the substitution of more resistant varieties of the potato (including some with higher total-solanidine content) and the introductions of haulm destruction and early lifting? before the blight reaches the tubers have kept its ravages at bay. Other methods of control, including? spraying with fungicides, have also played ano important part. The fungus is, however, now present wherever the potato is grown, practically throughout the world. Madagascar may be an exception, af least as recently as 1960 . In many parts, a blight year is customarily distinguished from other years merely by the date at which it would be expected that $75 \%$ of the haulms would be dead if left alone. Another criterion, less used but more appropriate in present context, is the proportion of tubers damaged by blight.

Partial resistance to certain strains of the fungus is a property of some varieties of potato, and the genetic basis has been well studied. Resistance of the haulm is often similar to that of the tuber but there are many exceptions. Hot or cold or dry condi $\frac{O}{3}$ tions will arrest sporulation (which takes place on the haulm of the potato plant) and thereby arrest the rapid spread of the fungus.

In suitable weather, spores washed down through the soil germinate, and the tuber is invaded, usually in the eye region. Spread of the mycelium throughout the tuber is often rapid but some tubers are able t $\varnothing$ halt the infection, particularly at low temperatures The rotting process is sometimes greatly accelerate $\$$ by any secondary bacterial infection that occurs Surprisingly, in storage the spread of the myceliur from tuber to tuber is reputed to be at most a uncommon event. At the end of winter, althougR only a small proportion of the surviving tubers iN recognizably infected with the fungus, that propor tion will generally be greater in a bad blight seasono

The toxic coumarins that are known to be syno thesized by the fungus itself, even when grown of minimal medium (Austin and Clarke, 1966), ma or may not be teratogenic. The same compounds -7 coumarin, scopoletin, aesculetin, and umbelliferone -are, interestingly, synthesized in small quantities 
also by the uninfected potato tuber itself. An argument against their being causative in ASB derives from the low and steady infant mortality recorded for spina bifida in the United Kingdom in 1848 (Rogers and Morris, 1971) when the blight fungus was still ravaging crops in Ireland and the rest of the British Isles. No doubt there is considerable underreporting in these data but this ought not to have obscured totally a decline in mortality from spina bifida in 1852 after the blight epidemic had passed. This argument militates against any direct role of the blight fungus or its own metabolites in causing ASB. It will later be seen, however, that blight has a powerful indirect influence on the incidence of ASB in the presence of certain varieties of potato, introduced in the present century. In some parts of the the world the role of other fungi may need to be remembered, such as Alternaria solani (early-blight) in South Africa. And, at certain times, the potato-wart fungus may have been involved, as Dr. Martin suspected.

\section{Antibiotic Products of the Potato}

SolanIDINE This steroid alkaloid, $\mathrm{C}_{27} \mathrm{H}_{43} \mathrm{NO}$, toxic to fungi (Allen and Kuć, 1968; Allen, 1970) nematodes (Allen and Feldmesser, 1971), and man (Bömer and Mattis, 1924; Willimott, 1933; Sirotina and Spirina, 1948; Wilson, 1959), is present in the potato largely as a range of glycosides, the solanines and chaconines. Schreiber (1968) gives a valuable review of the chemistry of the whole group of nitrogenous steroid alkaloids of the potato and related species.

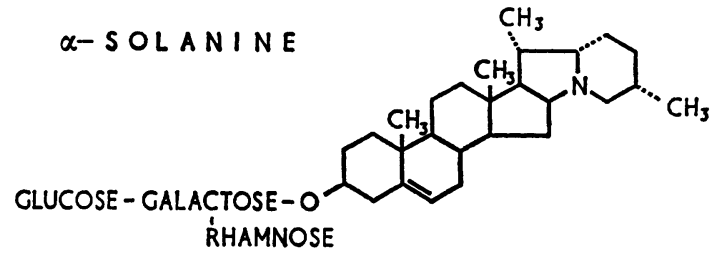

The total solanidine level is high in the skin and low in the pith of the tuber. This probably accounts for the fact that it is higher in small than in large tubers (Lepper, 1949). Light, particularly in the ultraviolet range of wave lengths, increases the level but only in the tuber skin and in the tissues immediately beneath it (Liljemark and Widoff, 1960 , and earlier authors). Injury also increases it (McKee, 1955; Gull and Isenberg, 1960). Time in storage is associated with a rise in the level (Gull and Isenberg, 1960), despite earlier claims to the contrary, and this may be exacerbated by injury. There are varietal differences in the level. Lepper
(1949), for example, reports high values in, among others, the Ackersegen variety, one of those known to have good field resistance to blight (Cox and Large, 1960). Majestic is another example of a variety with high total solanidine levels (Liljemark and Widoff, 1960) and a considerable resistance to blight of the tubers (Davidson, 1937). In North America, a recently introduced variety, LenapeB5141/6, which has considerable blight resistance, had to be withdrawn because of a high, indeed toxic, level of total solanidine in some stored tubers (Zitnak and Johnston, 1970).

The above facts taken in conjunction make it reasonable to deduce that solanidine glycosides play a part in resistance to blight. If this is so, then the definite tendency for blight-resistant varieties of potato to be favoured in bad blight areas would produce a secondary (though perhaps only weak) correlation in a geographical framework between the local severity of blight and the local levels of total solanidine in the potatoes surviving to be eaten. The correlation might be reinforced by early lifting in bad blight areas, resulting not only in smaller tubers with higher total solanidine concentration (Lepper, 1949) but also in a prolongation of the duration of winter storage of the tubers with consequent accumulation of glycosides.

In an earlier draft of this paper, the epidemiological data led to the conjecture that the blight fungus could induce steroid glycosides in some varieties of potato but not in others. (See sections on geographical distribution and secular trends.)

Since then, an important paper by Locci and Kuć (1967) has been brought to my notice by Dr. R. Riley and this establishes the conjecture-induction of a range of steroid alkaloids and perhaps other compounds in the Kennebec variety of potato when infected with an incompatible strain of Phytophthora infestans. No increase occurs in the blightsensitive variety Russet Burbank (compatible). It is believed that the $R_{1}$ (hypersensitivity) blightresistance allele that is present in Kennebec and some other varieties but not in Russet Burbank may be responsible.

This inducibility of steroid alkaloids implies that the severity of blight in an area would partly determine the total solanidine levels of certain varieties of potatoes grown in that area. (Lepper, 1949, in fact found big differences in total solanidine levels in tubers from a single variety grown in different regions of Germany. Some of these differences could be due to natural exposure to Phytophthora and other fungi.) The conjecture of a teratogenic role for a steroid alkaloid, originally advanced to account for the blight-ASB correlation 
in geographical and year-to-year distribution, thus gains considerably in plausibility. Certainly, there are other steroids that are known to be teratogenic (e.g., Fraser, Fainstat, and Kalter, 1953; Keeler, 1971).

Nishie, Gumbmann, and Keyl (1971) found $\alpha-$ solanine to be highly lethal to chick embryos. Some abnormalities were produced but teratogenicity was not established clearly. No report of teratogenic studies in mammals has come to light except that of Kline, von Elbe, Dahle, and Kupchan (1961) who fed 'solanine' (Aldrich) to pregnant rats. Intrauterine deaths were produced but no abnormalities of the fetuses were recorded. If none actually occurred, this could be because the special diets were administered only after pregnancy had been diagnosed by an increase in weight. This may have been after the end of the conjectured sensitive period.

A large part of what little is known about the metabolic fate, pharmacology, and toxicology of these glycosides has been contributed by Nishie et al. (1971) who also review a part of the literature. A few points need mention here. Only $1 \%$ or so of an oral dose is absorbed as such. Most of the ingested molecules are at least partially hydrolysed in the gut, and the resulting products, including solanidine, are largely excreted in the faeces and urine. Nishie et al. found that, contrary to earlier suggestions, solanines are much more toxic than solanidine. Cardiotonic effects (simulating those of K-strophanthoside) and, more strikingly, depression of the central nervous system lead to death. For man, an oral dose of $3 \mathrm{mg} / \mathrm{kg}$ produces neurological symptoms (Rühl, 1961). There is great variation in toxicity between mammalian species, and some of this presumably reflects the variation in the gut flora.

Since hydrolysis in the gut, by the microbial flora or otherwise, is so important in determining the blood level, any glycoside of such a structure that it escaped hydrolysis could potentially be absorbed unchanged and thus reach a critical concentration in the blood. The teratogen we are seeking for the oral route need not, therefore, be one of the most abundant glycosides in the potato. Indeed, since very low concentrations of a teratogen have sometimes produced congenital abnormality, quantitative factors alone are unlikely to discriminate between alternative routes or between alternative compounds as the teratogenic agent.

RIshitin AND Phytuberin These antifungal compounds, found only in traces in uninfected tubers, are synthesized by certain varieties in response to infection by certain strains of Phytophthora infestans (Tomiyama et al., 1968; Varns, Kuć, and Williams, 1971). They thus belong to the class of phytoalexins. Both are terpenoids, rishitin having the empirical formula $\mathrm{C}_{14} \mathrm{H}_{22} \mathrm{O}_{2}$ (Katsui et al., 1968) and phytuberin the formula $\mathrm{C}_{17} \mathrm{H}_{26} \mathrm{O}_{4}$ (Varns et al., 1971). Sato, Tomiyama, Katsui, and Masamune (1968) made the important observation that tubers would accumulate rishitin when dipped into a homogenate of the fungus, even though this was cell-free. This fact raises the possibility that tubers that are stored next to blighted tubers might produce this and other compounds (including some steroid alkaloids) while remaining uninfected themselves.

There are, so far, insufficient data to indicate which group of compounds is most likely to include the actual teratogen. Indeed, like cyclopamine from Veratrum californicum that produces the cyclops single-eye malformation of lambs (Keeler, 1969, 1971), the teratogen from potato may not be a previously known compound. (It is not yet known whether cyclopamine, now identified as the steroid alkaloid, 11-deoxojervine, is also responsible for the cyclops abnormality in man [Ingalls and Klingberg, 1965; Nishimura et al., 1966].) Dr. D. D. Clarke (1972 unpublished) has recently isolated several cinnamic acid derivatives that the potat synthesizes in response to Phytophthora infection Again, little is yet known of their teratogenicity.

\section{EPIDEMIOLOGICAL EVIDENCE}

\section{Geographical Distribution}

There is a striking correlation over a range of geographical areas between the ASB incidence and the average severity of the blight and this is clearly greater than the correlation of ASB with potato acreage itself, as may be seen from Figures 1 to 7 . For example, potatoes are grown in Idaho, U.S.A., in considerable quantities but because the low atmospheric humidity is unsuitable for sporulation and hence for spread of the fungus, the blight is a minor problem (Figs. 2 and 3; Cox and Large, 1960): so is ASB (Alter, 1962; Hewitt, 1963; 1965). In the wetter and more temperate states of New England, the blight is a more serious problem and so is ASB (Fig. 4). In southern Canada also, there is the same cline in blight and ASB incidence declining from east to west (Table I). The Province of Quebec is an outlier from the cline in having an excessive level of ASB (3.4 per 1,000,total birthsHorowitz and McDonald, 1969). Cox and Large $(1960$, pp. 148, 150) state that the blight control programme was inadequate in many parts of Quebec and tuber damage often severe; so the correlation between ASB and blight appears to be upheld. Moreover, within Alberta, the ASB incidence is 


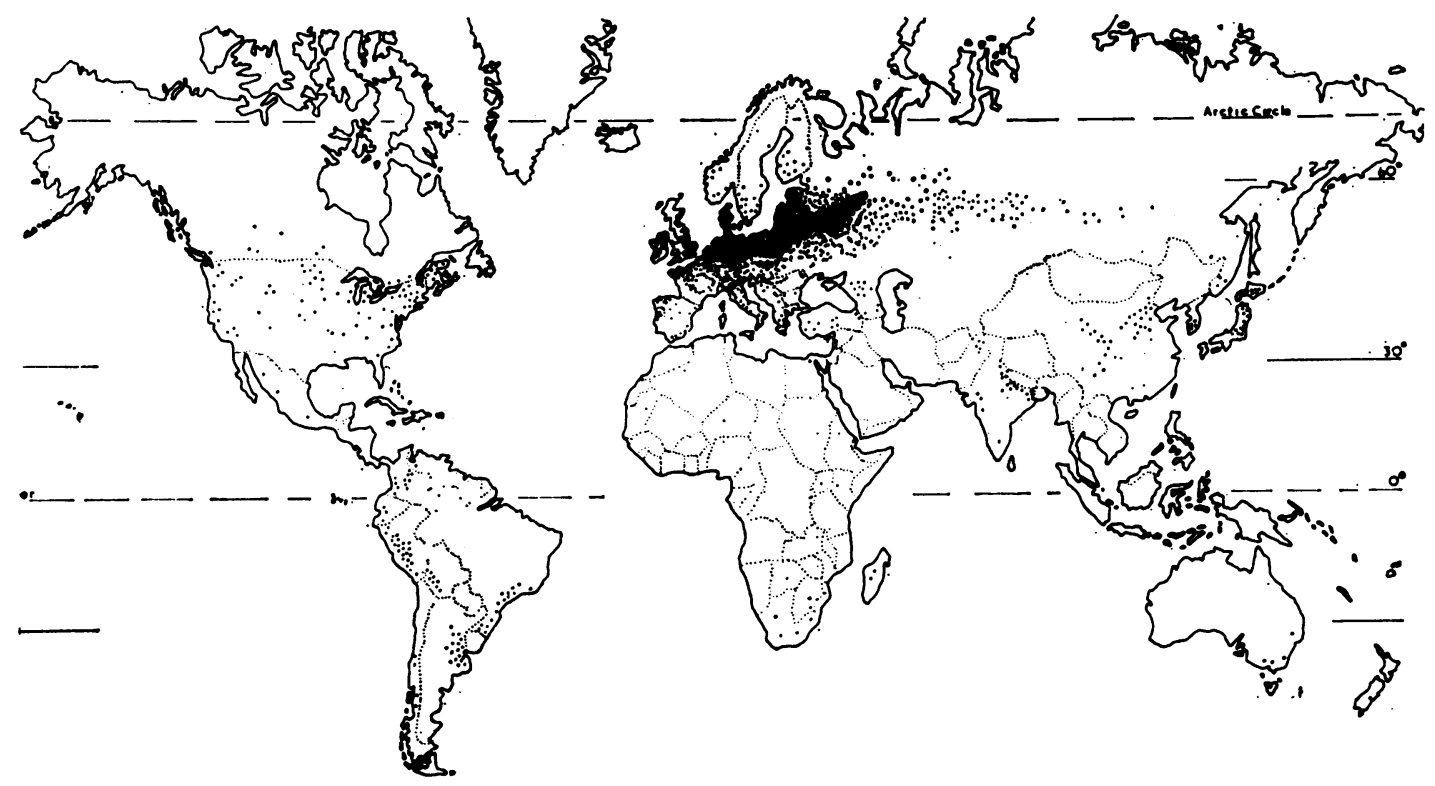

Fig. 1. World distribution of cultivation of potatoes, each dot denoting about 25,000 acres. Reproduced from Cox and Large (1960) with modification.

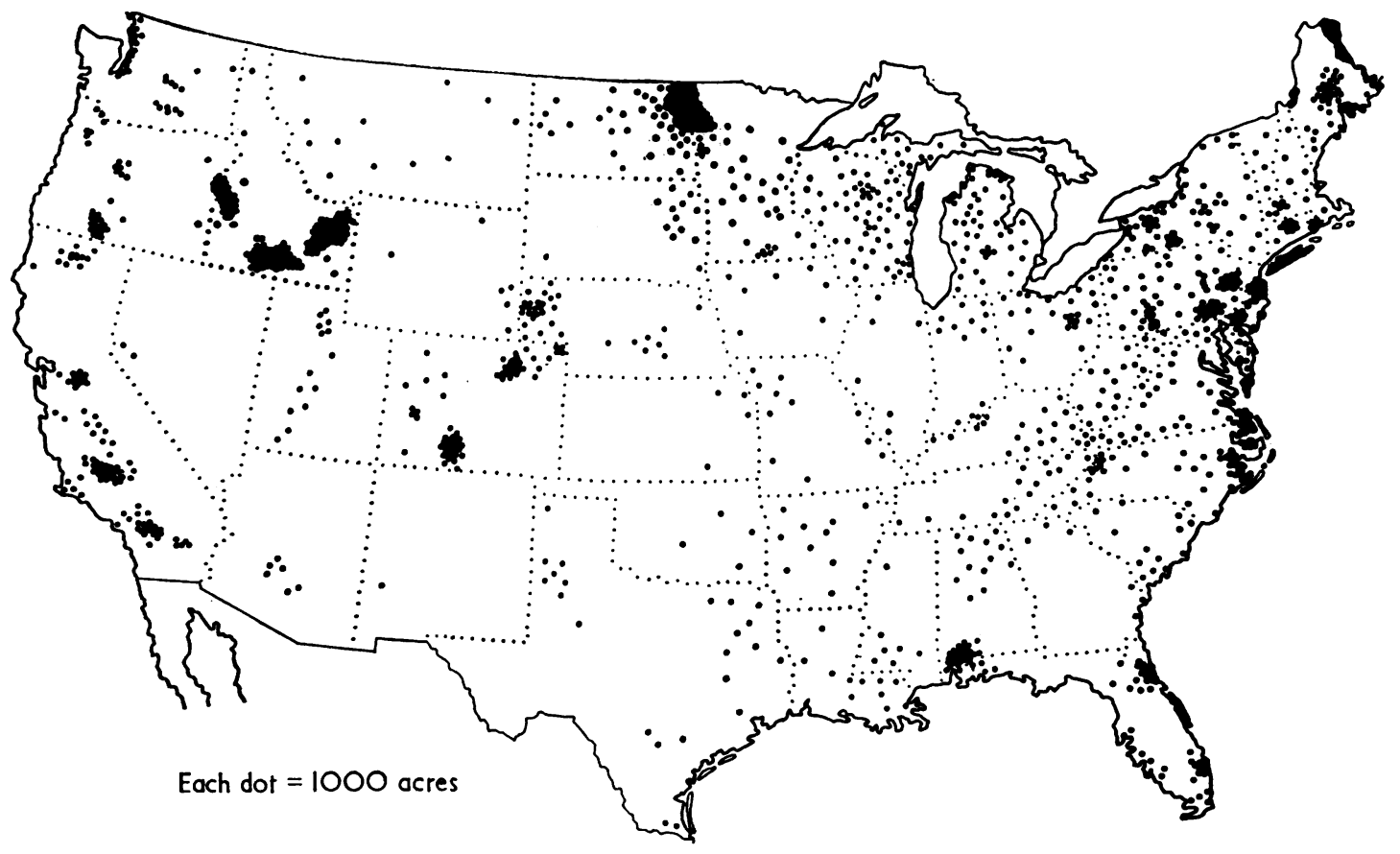

Fig. 2. Distribution of cultivation of potatoes in the United States, 1953. Reproduced from Cox and Large (1960). 


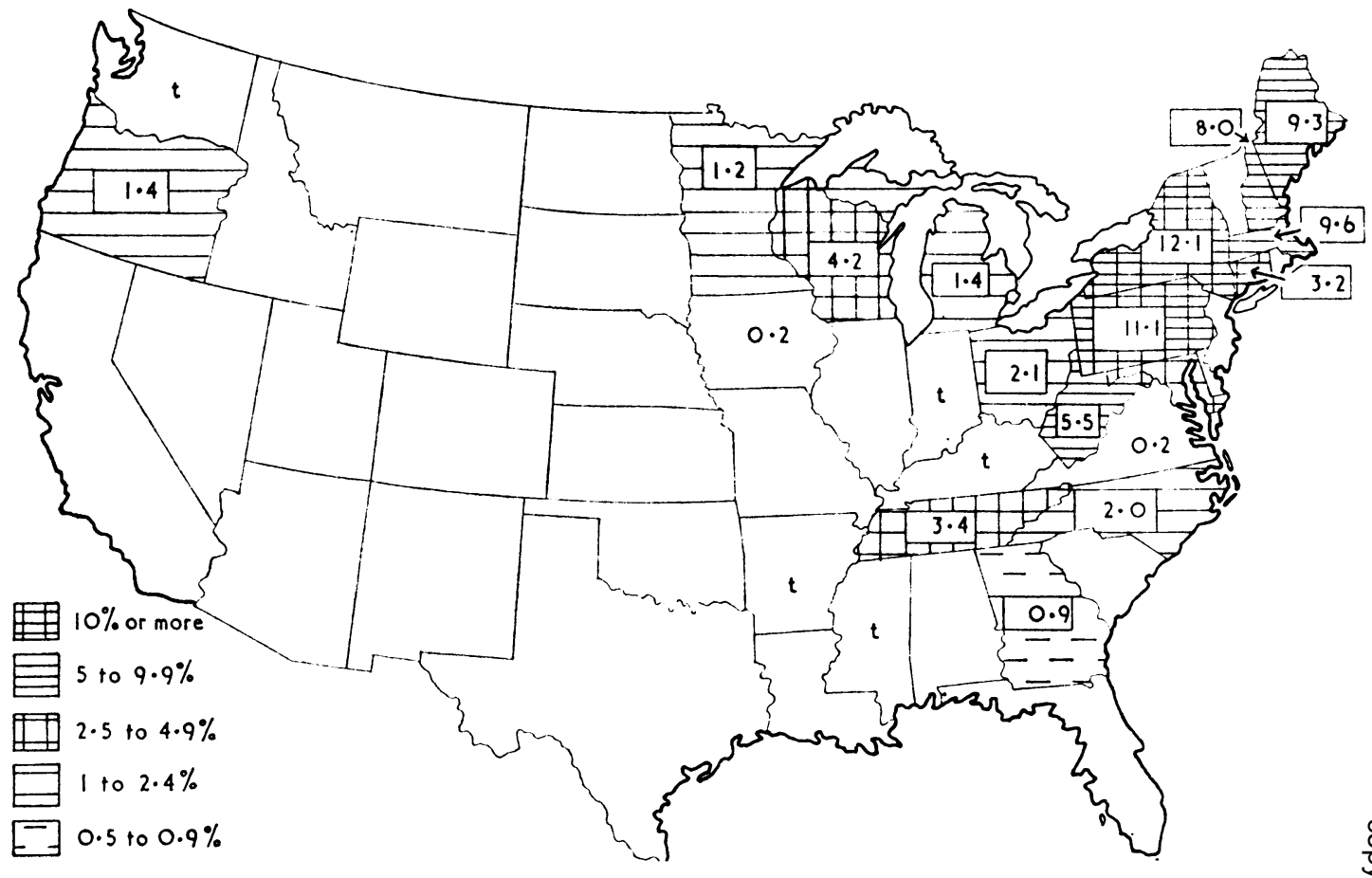

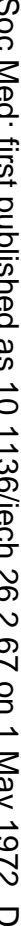

Fig. 3. Percentage losses of potato crop from blight in the United States, 1920-29: t denotes trivial loss. After Barrus, Boyd, and Wood $\underline{\bar{Q}}$ (1931).

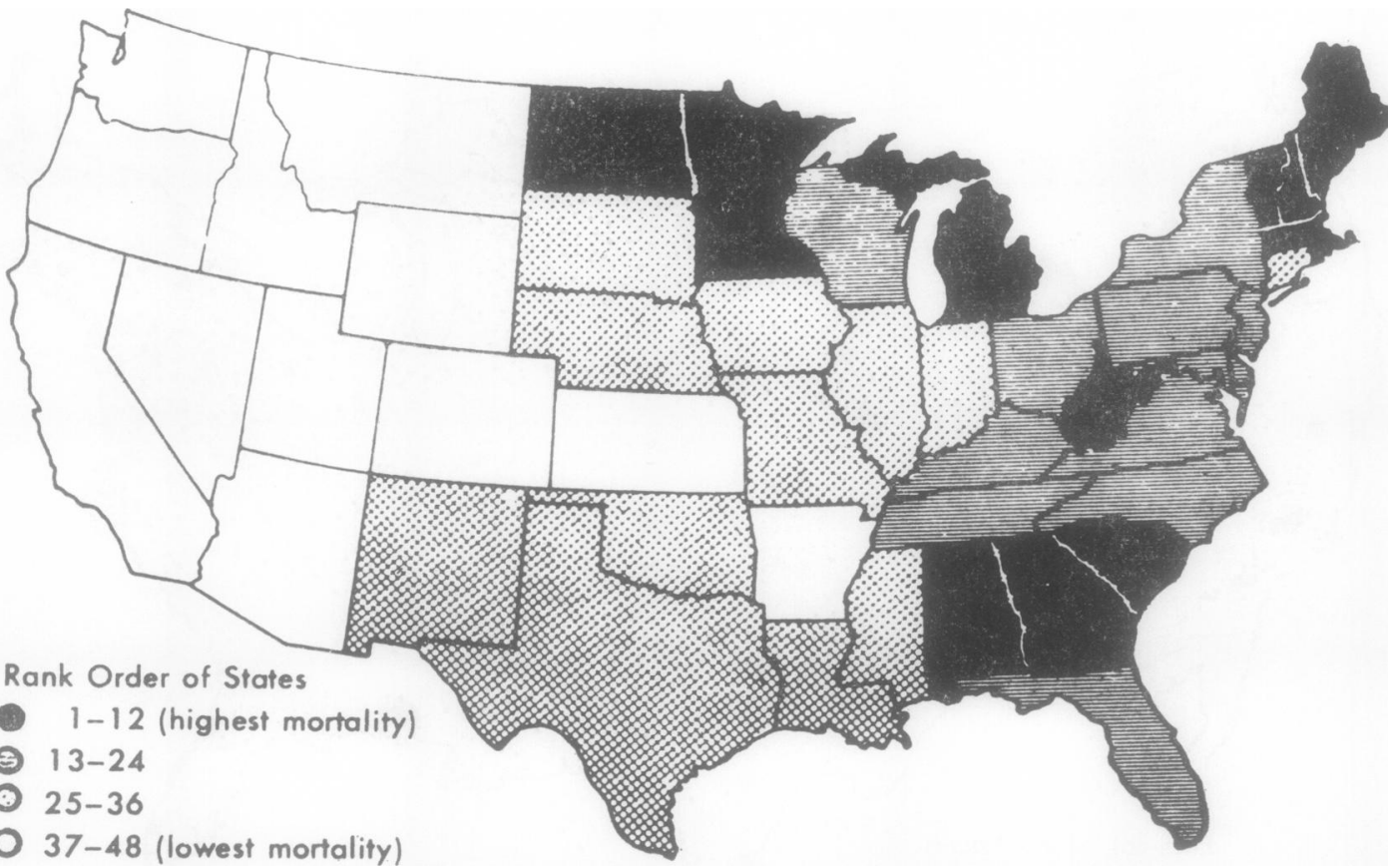

FIG. 4. Mortality of white infants attributcd to spina bifida and meningocele in each state of the United States, 1950- 59 . There is an evident correlation over the states between this mortality and the severity of potato blight as depicted in Fig. 3. Reprodiced fro:n Hewitt (1963). 
TABLE I

MORTALITY DUE TO SPINA BIFIDA AND ESTIMATED INCIDENCE OF ASB IN CANADA (AFTER HEWITT, 1965)

\begin{tabular}{|c|c|c|}
\hline & $\begin{array}{l}\text { Mortality } \\
\text { from Spina } \\
\text { Bifida per } \\
\text { 10,000 Live } \\
\text { Births }\end{array}$ & $\begin{array}{c}\text { Equivalent } \\
\text { ASB Incidence } \\
\text { (approx.) per } \\
\text { 10,000 Total } \\
\text { Births }\end{array}$ \\
\hline $\begin{array}{l}\text { Newfoundland and maritimes } \\
\text { Quebec (also Horowitz and } \\
\text { McDonald, 1969) } \\
\text { Ontario } \\
\text { Manitoba (also Choi and Peters, } \\
\text { 1969) } \\
\text { Saskatchewan } \\
\text { Alberta (also le Vann, 1963) } \\
\text { British Columbia }\end{array}$ & $\begin{array}{r}9 \cdot 8 \\
11 \cdot 7 \\
8 \cdot 0 \\
6 \cdot 9 \\
5 \cdot 3 \\
4 \cdot 6 \\
4 \cdot 1\end{array}$ & $\begin{array}{l}24 \cdot 5 \\
29 \cdot 3 \\
20 \cdot 0 \\
17 \cdot 3 \\
13 \cdot 3 \\
12 \cdot 5 \\
10 \cdot 3\end{array}$ \\
\hline
\end{tabular}

-Calculated by adding $25 \%$ to the spina bifida mortality to take account of stillbirths and doubling the result (see Introduction).

even lower in the south of the Province (le Vann, 1963), where the low humidity is unfavourable to blight, than in the north which has a higher rainfall and some blight (Cox and Large, 1960).

Ireland's mild and wet weather is highly suitable for the blight fungus, and Ireland also has the world's record for ASB (Penrose, 1957). The incidence in Belfast and Dublin averages nearly $1 \%$ of all births (Stevenson and Warnock, 1959; Elwood, 1970a); that in Cork is about 0.5\% (Spellman, 1969). The potato acreage in England and Wales is illustrated in Figure 5. The wet western

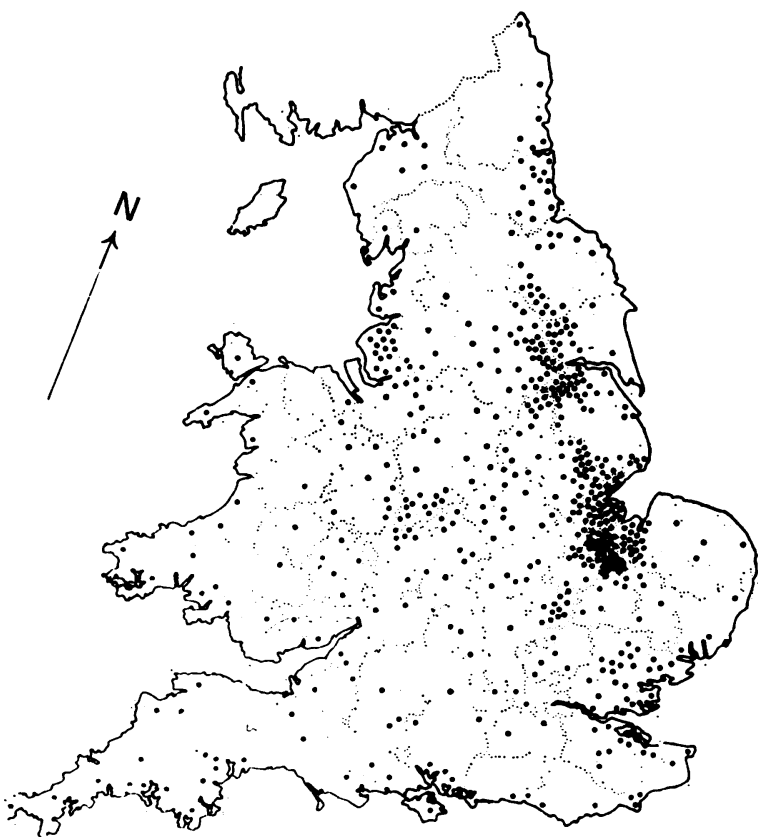

FIG. 5. Distribution of cultivation of maincrop potatoes in England and Wales, each dot denoting 1,000 acres. Reproduced from Cox and Large (1960).

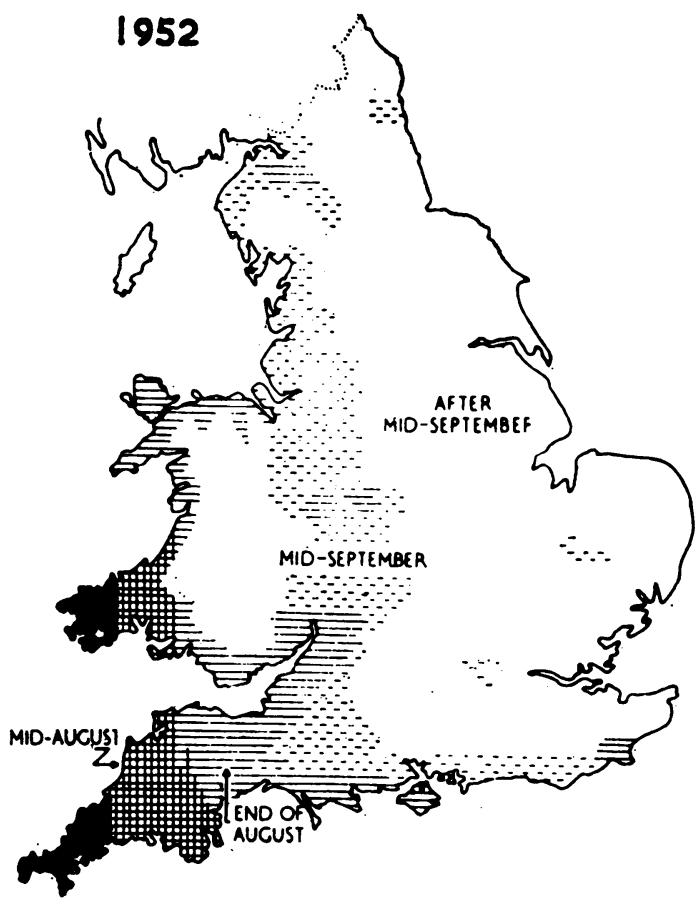

FIo. 6. Severity of blight in England and Wales, according to the date at which the $75 \%$ blight stage was reached on unsprayed main crop potatoes in 1952, a fairly typical year. Reproduced from Cox and Large (1960).

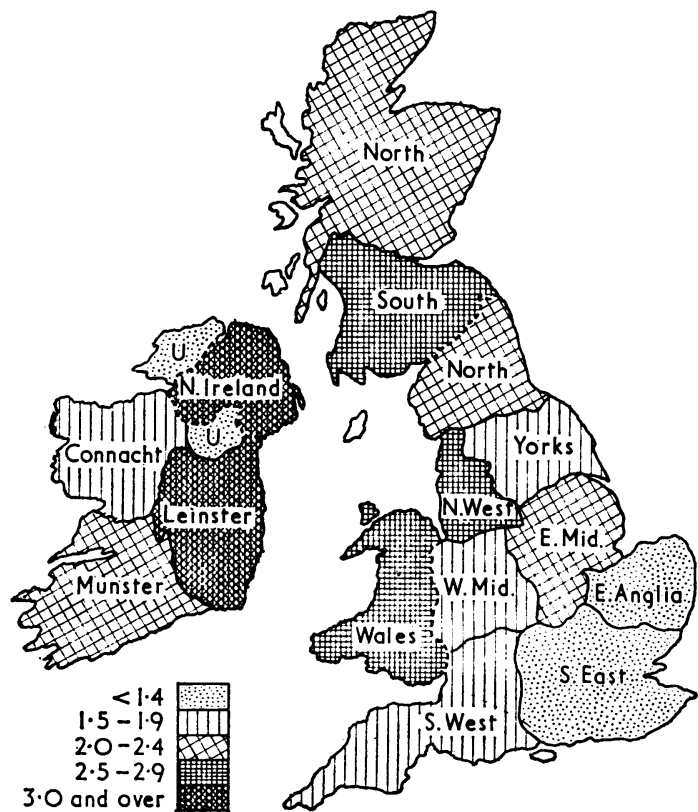

Fig. 7. Incidence (per 1,000 total births) of anencephalic births, (live and still) by region, 1965-67. There is believed to be some underreporting in the western parts of the Irish Republic. In this period, as in most periods, blight was more severe in the west, as in Fig. 6 , for example. Reproduced from Elwood (1970b). 
TABLE II

POTATO CONSUMPTION, PREVALENCE OF BLIGHT, AND INCIDENCE OF ASB ACCORDING TO REGION

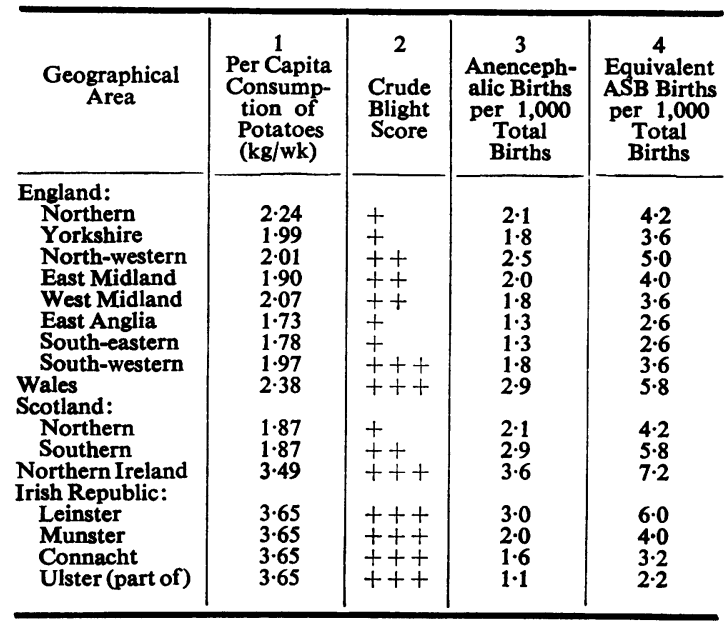

Consumption of potatoes per head in the U.K., 1967 (Ministry of "Agriculture, Fisheries and Food, 1969) modified to be consistent with "Food moving into consumption" data used in Figure 11. Consumption within Scotland and within the Irish Republic has been arbitrarily taken to be uniform within each country. Consumption data for Northern Ireland and the Irish Republic are equivalent to those given by Cox and Large (1960). The score of average severity of blight attack, also based on their data is given by region in column 2 and the population anencephaly incidence for 1965-67 is given by region in column 3, from data of Elwood (1970b). The equivalent ASB incidence is given in column 4.

regions are suitable for the fungus (Fig. 6) and they have high ASB rates (Fig. 7; Table II) (Laurence, Carter, and David, 1968; Elwood, 1970b). A belt of both blight and ASB extends eastwards across the whole of Europe at the latitude of Ireland. Both tend to decline eastwards into Russia at the eastern end of the belt (Cox and Large, 1960 (e.g., Fig. 56); Penrose, 1957). This belt also corresponds to the area of the world in which potato growing is most intensive (Fig. 1). In Norway, the peak infant mortality rate (0-3 years) for spina bifida among liveborn infants occurs in the county of Vest-Agder at the southernmost tip (Westlund, 1969), where the severity of blight is maximal. Unfortunately, Westlund's anencephaly data cannot be used to reinforce this as they concern only those births registered as live and it is well known that, for anencephaly, the classification as live or stillborn is somewhat arbitrary. In northern Norway, but not in other parts, most anencephalics appear to be registered as liveborn and this gives a spurious excess of mortality from this cause in the north.

For France, most of the regional data are based on questionnaires (Frézal, Kelley, Guillemot, and Lamy, 1964). There is internal evidence of incomplete and varying reporting and no simple pattern of incidence emerges. In Brittany, even in bad blight years (which are the majority), tuber infection iso slight. The popular variety there is Bintje which is very blight-sensitive, and infected tubers are, there-\$D fore, rather unlikely to survive to be eaten. The low ASB incidences, 1.0 per thousand births, ares therefore reconcilable with the hypothesis. Theo highest ASB incidence is in the Pas de Calais, anow ther blight area. Here the presence of a proportion $\overline{\bar{n}}$ of the high-solanine, blight-resistant variety, called $\bar{B}$ Ackersegen, probably accounts for this. The lowesto ASB incidences are in the areas of Lyon and the upper Rhine (0.4-0.6 per 1,000 births) where the blight is least troublesome.

ASB data are available also for Czechoslovakia $\stackrel{\omega}{\stackrel{\omega}{~}}$ Denmark, Finland, Germany, Holland, Italy Jugoslavia, Spain, Sweden, Switzerland, and other parts of Europe (Böök and Rayner, 1950; Böök andō Fraccaro, 1956; Penrose, 1957; Beolchini and? Bailo, 1965; Kučera, 1965; Källén and Winberg, 1968; Canzler, Funk and Schlegel, 1969; Czeizel and음 Révész, 1970; Kuypers and Huisjes, 1971). Theyare not always easy to interpret but incidences 3 appear to follow the pattern indicated by Penrose (1957), who was the first to emphasize the value of $\overrightarrow{0}$ studying the regional differences. Blight severity is âs N yet rather difficult to compare from country country but, roughly, the distribution of its severi in Europe follows that for potato acreage (Fig. $\rightarrow$ ) except that upon it is superimposed a west-to-east decline in severity. It comes, in fact, to resemble $\bar{\perp}$ rather closely the distribution of ASB incidence.

Some potatoes are grown in the Nile delta and it may be relevant that Stevenson, Johnston, Stewart, and Golding (1966) have quoted a moderate inci-o dence of ASB $(5.4$ per 1,000) in hospital births in Alexandria. Further, Damyanov and Dutz (1971) report a figure of 3.2 per 1,000 hospital births in Shiraz, Iran; and Abou-Daoud (1966) reports 63 . per 1,000 hospital births in Beirut, Lebanon. Potato blight is also present in all three countries 3 (map 109 of Commonwealth Mycological Institute, 음 1969) and also, to some extent, in the northern part of Israel, from which country low ASB inci- $\frac{D}{0}$ dences are reported by Halevi (1967) and Naggan (1971).

The blight fungus reached India in the $1880 \mathrm{~s} N$ and the potato crop is often severely damaged, 命 particularly in northern parts of the subcontinent $\frac{\omega}{\sigma}$ (although in some other parts the climate is too hot or too dry for the fungus to flourish). ASB is not rare in the north; for example, Stevenson et al. $\stackrel{\$}{+}$ (1966) quote figures of 4-8 per 1,000 total births (stillborn and liveborn) in Amritsar Hospital. It ${ }^{\circ}$ would be unwise, however, to comment further on $\vec{\Phi}$ the correlation between blight and ASB in the $\frac{?}{\mathbb{Q}}$ 
Indian subcontinent (where the potato is rather a luxury) without considerably more data on each. Kolah, Master, and Sanghvi (1967) give ASB data for Bombay.

Penrose (1957), Green (1964), and Stevenson et al. (1966) quote low figures for ASB (usually less than 1 per 1,000 births in hospital) for peoples of African origin. These low incidences, which apply also in much of the far east, including Hong Kong, Fiji, Manila, and Taiwan (Wei and Chen, 1965), are here taken to represent a background incidence of unknown origin against which the 'potato effect' is set off. The incidence in Melbourne (Collmann and Stoller, 1962) and in Sydney (Jones, 1967), to judge from hospital populations, is slightly higher (1.2 and 1.5 per 1,000 hospital births). The cultivation of the potato in the areas surrounding Melbourne is indeed extensive. The weather is variable but only occasionally leads to blight. Potato consumption is relatively small (about $1 \mathrm{~kg}$ per head per week).

In the Auckland area of the northernmost part of New Zealand, the ASB incidence is about 4 per 1,000 total births in hospital (Howie and Phillips, 1970). This is roughly comparable with that in Birmingham, UK. Blight is severe, largely because of the carry-over of infection from one crop to the next that is permitted by the practice of year-round cultivation. The incidence of ASB would presumably be higher but for the relatively low per capita consumption of potatoes $(0.9 \mathrm{~kg} /$ week) compared with about double that figure for England.

In the south of Japan, few potatoes are grown or eaten and the incidence of ASB (0.8 per 1,000 total births) is low (Neel, 1958; Nishimura et al., 1966). In the northern half of the country, the potato is widely grown and contributes to the diet but, unfortunately, no published estimates of ASB incidence for the north are readily available.

Few suitable data are available from South America. Chile is of particular interest because blight did not reach the island of Chiloe and thence the mainland until 1949. There was a severe epidemic in 1951. The Ackersegen and Voran varieties of potato, which have moderately high solanine content (respectively 10 and $9 \mathrm{mg} / 100 \mathrm{~g}$ : see Lepper, 1949) and blight resistance (Cox and Large, 1960), have since then been replacing the sensitive Corahila variety previously preponderant in Chile. Cruz-Coke (1970 and unpublished) has pointed out a doubling in recent years in the frequency of anencephaly.

In Colombia, potatoes that are grown at a high altitude are relatively free of blight. The malformation data of Stevenson et al. (1966) suggest that ASB incidence is low in the hospitals in Bogotá and Medellin ( 0.3 and 0.5 per 1,000 hospital births), but Böök and Fraccaro (1956) quote a much higher figure for Colombia as a whole $(4 \cdot 8$ per 1,000$)$.

Blight occurs in the large potato crop of southern Brazil but details are not yet available. The incidence of ASB (1.9 per 1,000 hospital livebirths and stillbirths) may be rather less than in south-east England (Stevenson et al., 1966).

The world-wide distributions of blight and ASB are thus compatible with at least an indirect role for the blight fungus in the induction of ASB.

\section{Occupational Class}

The striking excess of ASB in the lower paid occupational classes that was demonstrated by Anderson, Baird, and Thomson (1958) and Edwards (1958) has been confirmed in most other studies in the British Isles and most recently by Fedrick (1970a). Even before 1958, a correlation of ASB with low serum protein and with low haemoglobin concentration in the mother was found by Coffey and Jessop (1957). It presumably reflects the same type of influence.

On the hypothesis of a percutaneous route of entry for the teratogen, the least privileged occupational groups (V) have, by comparison with the most privileged (I), a greater exposure of the skin to teratogen because of a greater weight of potatoes to be peeled, compounded by a greater exposure risk per kilogramme. The greater weight of tubers results from:

1. greater consumption per head, as seen in Table III. In 1967 in England and Wales this excess was $44 \%$ (Ministry of Agriculture, Fisheries and Food, 1969).

2. less eating out

$$
\text { Factor }=1 \cdot 44: 1
$$

3. no domestic help

$1 \cdot 10: 1$

The greater exposure risk per kilogramme of potato results from:

(a) greater relative time (seconds/gramme) taken to peel the small tubers which are less frequently discarded

(b) longer handling per tuber if blighted parts are excised and the rest is rescued

(c) greater concentration of teratogen, on average, in tubers peeled, due to a proportion being blighted

(d) greater concentration of teratogen, on average, in tubers peeled, due to a greater proportion being 'old' (and, at certain seasons, much cheaper than new potatoes)

(e) greater concentration of teratogen, on average, in tubers peeled, due to a greater proportion being small

Cumulative product if all factors independent 
These figures are no more than plausible guesses in many cases and are given merely to demonstrate that there is, so far, no reason to discard a fairly simple relationship between amount of teratogen absorbed through the skin and the risk of ASB. Edwards (1958) and Wilson (1971) found a fourfold difference in the ASB incidences in occupational classes $\mathrm{V}$ and $\mathrm{I}$ in Scotland and Glasgow respectively and this could be reconciled with the above cumulative factor by a minimum of adjustment of some of the ratios. In Belfast, Elwood (1970a) found a threefold difference.

An alternative hypothesis of an oral route for a potato teratogen can be reconciled, in a similar manner, with an occupational class factor of three or four.

TABLE III

POTATO CONSUMPTION IN BRITAIN, 1967, ACCORDING TO OCCUPATIONAL CLASS

\begin{tabular}{l|c}
\hline Class & $\begin{array}{c}\text { Per Capita } \\
\text { Consumption } \\
\text { of Potatoes } \\
\text { (kg/wk) }\end{array}$ \\
\hline A1 & 1.54 \\
A2 & 1.63 \\
C & 1.99 \\
D1 & 2.07 \\
\hline All households & 2.13 \\
\hline
\end{tabular}

Classes A1, A2, B, C, and D1 correspond very approximately to the older classes I to $\mathrm{V}$ respectively. Data from Ministry of Agriculture, Fisheries and Food (1969).

\section{DIET OF THE MOTHER}

Pitt and Samson (1961) found a significant (23\%) excess of carbohydrate intake and Richards (1969) an unbalanced diet in the mothers of ASB infants compared with controls. No details of potato consumption are published but Richards (1969) found mothers of anencephalics to be significantly heavier than controls (the time of weighing being in the first trimester or previously).

\section{Season of the Year}

In several studies in Great Britain (McKeown and Record, 1951; Edwards, 1958, 1961 ; Record, 1961; Slater, Watson, and McDonald, 1964; Leck and Record, 1966; Elwood and MacKenzie, 1971), a winter excess in the incidence of anencephaly has been detected, particularly in December. Spina bifida cystica tends to have maximum incidence in births in February (Guthkelch, 1962). The difference of nearly two months in the peak time for anencephaly and that for spina bifida (Guthkelch, 1962; Wilson, 1971) has been plausibly attributed by Guthkelch to the seven weeks shorter modal duration of gestation of the anencephalic fetus (see
Laurence et al., 1968) due to the hydramnios that 0 often accompanies it. The time of injury to the $?$ embryo may well be almost identical in the two conditions, i.e., in the U.K., maximally in May at about the third week of gestation. At this time of $\frac{\overrightarrow{\bar{s}}}{\mathrm{~s}}$ year the old potatoes are from main crop or late $\overline{0}$ varieties. Such varieties tend to be relatively resist- $\frac{C}{0}$ ant to the blight fungus, otherwise most of the crop $\frac{\bar{m}}{\bar{m}}$

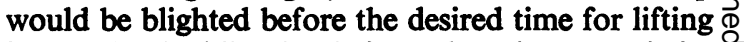
it. Total solanidine levels in such resistant varieties are comparatively high and, by May, these levels ${ }^{\infty}$ have risen further on storage, particularly in those $\vec{\circ}$ tubers that are partially blighted.

A similar seasonal effect has been reported in $\stackrel{\omega}{\circ}$ Israel (Halevi, 1967), Iran (Damyanov and Dutz, 1971), Germany (Tünte, 1968), Italy (Beolchini and $\stackrel{?}{?}$ Bailo, 1965), and Hungary (Czeizel and Révész, 요 1970). In Alabama, where blight is sometimes ? troublesome at least on high ground, the rise in ASB 9 incidence is curtailed a few months early (Cassady, 음 1969), possibly reflecting the fact that the need for winter storage of potatoes in that state is of shorter $z$ duration than in states with longer winters. The peak incidence, which is not high, occurs in (approxi- $\overrightarrow{0}$ mately) August and represents conceptions $N$ January with teratogenesis in February. Hungary hes a comparatively long winter and shows a shift the peak in the opposite direction: there it is con ceptions in June that have the highest risk of ASB.

\section{URBANIZATION}

The incidences of ASB in towns are often about twice those in the surrounding country (Pleydell, 1960; Laurence et al., 1968; Horowitz and McDonald, 1969), though apparently not in Israel (Halevi, 1967). The excess might be due to injury $\stackrel{\circ}{?}$ (and delay) inflicted on the tubers during handling and transportation to the towns. Both injury and 3 delay increase the total solanidine content. Perhaps also, the greater availability of other vegetables in 3 rural areas may diminish the role of the potato in $\mathrm{O}$ the rural diet.

The town of Singapore receives its potatoes from $\frac{7}{0}$ high altitude regions of Malaysia and particularly from Australia. The length of this transit possibly $\widetilde{O}$ affects the quality of the tubers, and those mothers $N$ who handle potatoes might have an extra risk from N the products of infected and secondarily infected $\omega$ tubers. Among the Sikhs, the per capita consumption of potatoes, though not high, is higher than that of most other Asian peoples in Singapore and $\stackrel{\Phi}{\oplus}$ the number of persons in the household is considerable. Searle (1959) found 6.5 anencephalic births 0 per 1,000 hospital births $(8$ in 1,230). The corres- $\mathbb{\Phi}$ ponding ASB incidence is $1.3 \%$ but is likely to be $\stackrel{\odot}{\stackrel{\rho}{\circ}}$ 
even more inflated than other hospital rates because of the strong pressure for the reservation of hospital places for mothers with hydramnios or other abnormality.

\section{Maternal Age and Parity}

Maternal age and parity are closely correlated with each other. Penrose (1946), Record and McKeown (1949), Edwards (1958), Record (1961), and Fedrick (1970a) have, however, shown an excess of ASB in the first-born, independently of maternal age, and this has been confirmed in other British studies. Except for the first birth, the incidence of ASB certainly rises strikingly with maternal ages over 30 years. The joint age and parity effects, as seen in the U.K., are summarized diagrammatically in Figure 8. A simple explanation can be given,

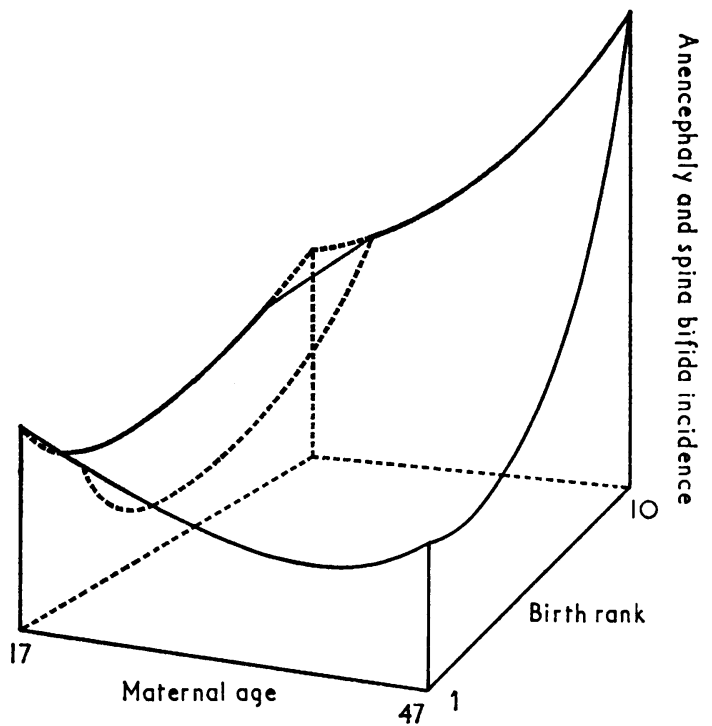

Fig. 8. Diagram to illustrate the boat-shaped relationship between, on the one hand, maternal age and child's birth rank jointly, and the incidence of ASB in Britain, on the other hand. Only approximately to scale. The remote corner is truncated as a gesture to the reality that there is a limit to the multiparity of young women.

in terms of the percutaneous teratogen hypothesis, that depends on the longer time taken to peel the potatoes that are required to satisfy more and bigger appetites as the family grows bigger and as ages (including that of the mother) rise. The excess risk for the first-born might reflect the fact that the first child is sometimes (or often) conceived before the mother leaves the family home. In such cases it is subjected to the same hazard, whatever that may be, as the higher parity offspring of the grandmother's family. Record and McKeown (1949) found an excess of ASB mothers living with relatives and this excess is presumably most pronounced among those of lowest age and parity. Once again, the ASB risk could be directly proportional to household appetite and its attendant potato-peeling implications at the precise time that the embryo is subject to ASB teratogenesis. In Israel, the primiparity effect is not found in the younger generation (Naggan, 1971), but it is quite clear in all age groups over 25 years. In the Irish Republic, where marriage is late and the gap between pregnancies is small, the primiparity effect is marked but other parity effects are small. Such regional and secular effects point to social factors rather than physiological ones, and they can readily be explained on a potatoteratogen hypothesis such as the above.

\section{Recurrence Risks in Sibships}

The risk of ASB when there is already an affected sib is several times greater than that for the general population, as would be expected from a continuing environmental hazard to that family on a teratogenic hypothesis (Record and McKeown, 1950b; Smithells, D'Arcy, and McAllister, 1968). In Britain, this risk among live and stillbirths averages about $5 \%$ (Williamson, 1965; Carter, Laurence and David, 1966; Lorber, 1965; Laurence, 1969). It rises to $10 \%$ after a second ASB sib (Carter and Roberts, 1967). Some striking sibships are described by Dunn and Salter (1944), Horne (1958), and Mufarrij and Kilejian (1963). In at least some families, the aggregation may owe something to a genetic or acquired idiosyncrasy of the mother-perhaps a relative inability to detoxify a teratogen, or an undue facility in converting some precursor from potatoes to a teratogen.

\section{Twin DATA}

There is, moreover, evidence for a low concordance rate for ASB in monozygotic (MZ) twin pairs. Yen and MacMahon (1968) found none of 30 same-sex co-twins of ASB infants to be affected; Record and McKeown (1951) found none of 35; Horowitz and McDonald (1969) found one of 35; Stevenson et al. (1966, Table 4.4) found one of 15; Butler and Alberman (1969) found none of 11; Gittelsohn and Milham $(1962,1965)$ found 9 of 60 , making a total of 11 of 186 same-sex co-twins. I make the approximation that about two-thirds of twin pairs are dizygotic (DZ) and are equally divided between twin-pairs of like sex and those of unlike sex, hence I estimate that 93 of the 186 like-sex pairs are $\mathrm{DZ}$. The $\mathrm{DZ}$ concordance rate is about 6\% (Gittelsohn and Milham, 1965), say 5.6 out of 93 . Thus, in the above sample, there may be 10.8 ASB infants belonging to $(5.4)$ concordant 
MZ pairs (11-5.6) and 87.6 to (87.6) discordant MZ pairs. The risk to the co-twin of an ASB infant is estimated to be $10 \cdot 8 / 98 \cdot 4$ or about $11 \%$. The proportion of ASB-containing $\mathrm{MZ}$ pairs that are concordant for ASB is $5.4 / 93$ or $5.8 \%$. These estimates, which correspond closely with those for DZ twin-pairs, are inconsistent with a major role for the embryo's genes, at least within an ethnic group. de Bellefeuille (1969) reaches a similar conclusion after reviewing case reports-which he acknowledges to contain a bias, probably towards concordance.

The risk (11\%) to any co-twin is higher than to a non-twin sib (5\%), as expected on the potato teratogen hypothesis. On this hypothesis, the low value of the risk even for co-twins may be explained in terms of chemical interactions of such slow kinetics that chance is a principal determinant of the outcome. Further, since it is likely that even MZ twin embryos frequently differ in the rate of development, the timing of a daily teratogenic hazard might happen to catch one twin at a critical, sensitive stage of short duration and to miss the corresponding stage in the co-twin. The inference on difference in the rate of development is by extrapolation backwards from a frequent disparity noted by Fogel, Nitowsky, and Gruenwald (1965) and others in full-term birthweight. This disparity exceeds $20 \%$ three times more often in $\mathrm{MZ}$ than in $\mathrm{DZ}$ pairs. Disparity of $\mathrm{MZ}$ twins in dead-or-alive status at birth is also more common (Stern, 1960). The nature of the origin of MZ twins by splitting of a single embryo at some early stage into two parts, often, we must presume, only approximately equal in the number of cells, certainly gives an opportunity for disparity between some sets of $\mathrm{MZ}$ twins right from the start.

\section{RACE}

The apparent unimportance of relevant genetic variability within an ethnic or racial group does not necessarily rule out an importance for such variability between groups. In fact, American Negroes have lower incidences than Whites in the same region despite lower average incomes (Erhardt and Nelson, 1964; Cassady, 1969). Penrose (1957; quoting Khan) and Stevenson et al. (1966) show just the same for the Bantu in South Africa, and Howie and Phillips (1970) show it for the Maori in New Zealand. Whether the difference is in the genetic backgrounds or in the potato customs or both is not known.

A genetic predisposition to ASB among the Irish has been invoked to explain Ireland's unique incidence rates. But Naggan and MacMahon (1967) and Leck (1969) have shown that, outside Ireland, the ASB incidence among the Irish falls off with each generation even in the absence of dilution of the gene pool. It comes to approximate that of the host population. The same regression or pro gression towards the incidence in the host populas tion has been noted for Indians and Pakistanis ing Birmingham (Leck, 1969), Puerto Ricans in Neve York (Erhardt and Nelson, 1964), and for immigrans groups in Hawaii (Morton, Chung, and Mi, 1967)@

No dogmatic conclusion on race effects can be reached: the evidence so far suggests that food customs contribute the variations in incidence. The contrast in the U.S. between negroid and caucasoid populations, if it is not due simply to Negro preference for the (safer) sweet-potat Ipomoea batatas or to some other cultural difference may conceivably owe something to intergroup genetic differences.

\section{Secular Trends}

A remarkable epidemic of anencephaly between the wars with a peak in 1932 was described bew MacMahon and Yen (1971) among births in hospi $=$ tals in Boston, Mass., and Providence, R.I. (Fig 9 9). The declining phase of this epidemic had ben

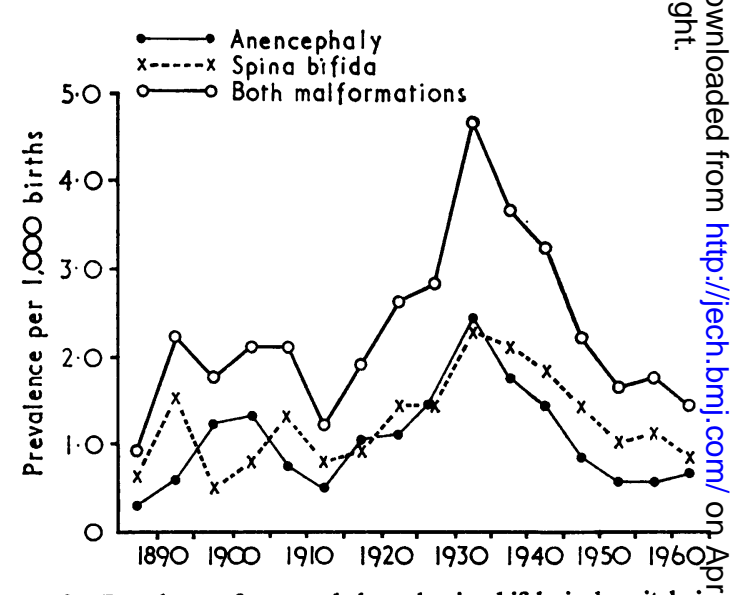

FIG. 9. Prevalence of anencephaly and spina bifida in hospitals if: Boston, Mass. and Providence, R.I., 1885-1965. Reproduced from

noted previously on other North American data bw Gittelsohn and Milham (1962) and Naggan (1969) The peak incidence reached 5 per 1,000 totâ hospital births compared with a base level of 2 per 1,000 . The cause of the epidemic is unknowm but it is tempting to attribute it either to the intro $=$ duction of the new blight-resistant varieties of potato that had just been produced or to the sprea $\Phi$ of central heating to ordinary homes and shops wit 
the consequent acceleration of microbial invasion of potatoes, among other foods. The decline phase was then initiated either by the institution of the U.S. blight warning system in 1931, accompanied by a vigorous spraying programme to control blight, which the new potato varieties had only temporarily checked; or to the spread of air-refrigeration equipment, in homes and shops, which counteracted the deterioration of food from central heating. Many other interpretations consistent with the potato teratogen hypothesis could be devised, involving the soup-kitchens with their potato base, for example, but the only purpose of mentioning them is to show that the epidemic does not constitute evidence against the hypothesis. The decline of ASB incidence is continuing (Ingalls and Klingberg, 1965), perhaps because of improved control of blight, or because of the shift of potato cultivation away from the blight areas of the east to the relatively blight-free areas further west, or because of the steady fall in potato consumption (Fig. 10).

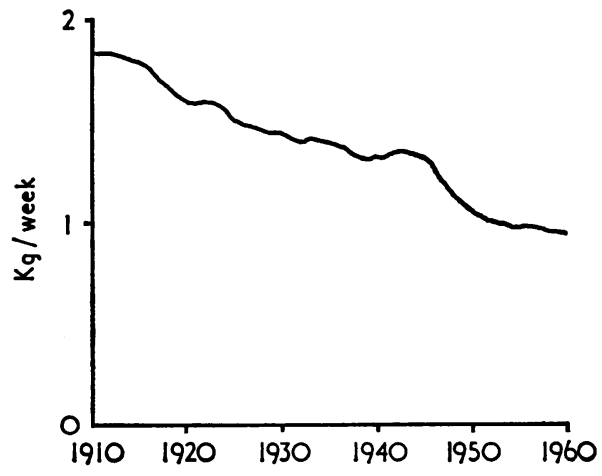

Fro. 10. Potato consumption per capita in the United States, 191060, modified from Stefierud (1959).

Starting at about the same time after the first war, there was a less dramatic increase in ASB incidence in Britain, as noted by Record and McKeown (1949) and Rogers and Morris (1971). The introduction of Majestic as a blight-resistant and wartresistant variety during and particularly after that war coincides roughly with the rise in ASB from 1918 to the year 1928, when a plateau rate was reached which has lasted with some fluctuations until the present. (The decline phases in the British spina bifida mortality data reflect improvements in therapy, not changes in incidence-sulphonamides from about 1942, penicillin from about 1946, various surgical repairs from about 1956 (see Leck, 1966).) As shown in Fig. 11, there has been no marked decline in potato consumption per head and there has been no consistent decline in ASB incidence. A blight warning system has been in operation in Britain since 1950 but it is only since 1958 , by which time nearly $70 \%$ of the Fens crop was being sprayed, that a real improvement in the blight situation has been observed and some of that might be attributed to weather conditions. Whatever the cause of that improvement, there seems to be a concomitant improvement in the ASB incidence in at least two of the towns that receive most of their supplies from the Fens area-Birmingham (Leck and Rogers, 1967) and Leicester (Moss, 1964).

The 1939 war seems to have started in the middle of a period of above-average ASB incidence in the British Isles (Leck and Rogers, 1967), such as might reflect a short run of blight years (not yet verified). A further rise in ASB incidence would have been expected to follow the war-time rise in potato consumption (see Fig. 11) but, instead, there

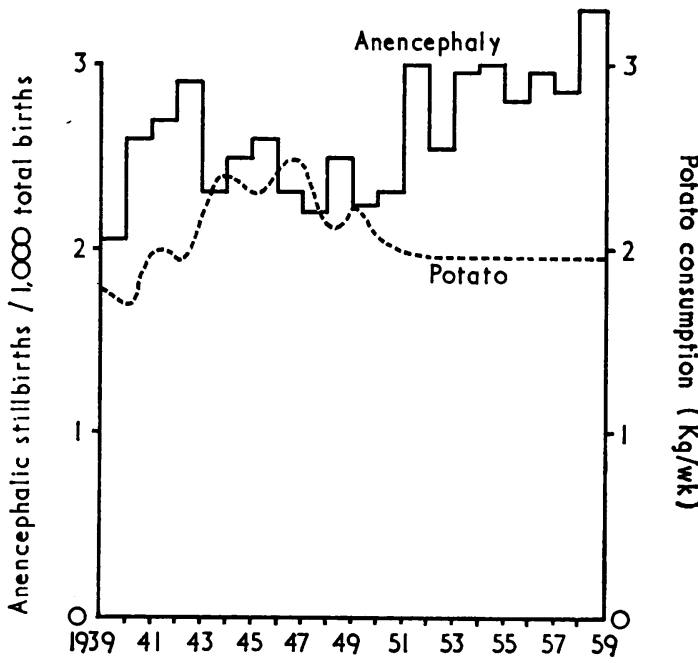

Frg. 11. Per capita consumption of potatoes $(\mathrm{kg} / \mathrm{wk})$ in Britain 1939-58. Also the incidence of anencephalic stillbirths by year of teratogenic insult. The lack of positive correlation is discussed in the text. After Record (1961) and Ministry of Food (1951) and Ministry of Agriculture, Fisheries and Food (1957, 1969).

was, if anything, a slight but sustained fall even in neutralist Dublin in 1942. The zoning policies of governments and the shortage of fuel for transport no doubt reduced the movement of potatoes and perhaps therefore their deterioration in transit that was discussed on page 76. Household and shop temperatures were lower and the preservation of potatoes may thereby have been improved further. Both these factors ceased to operate in Dublin soon after the war and, indeed, the ASB rates there rose in 1946-47, several years before they rose in 


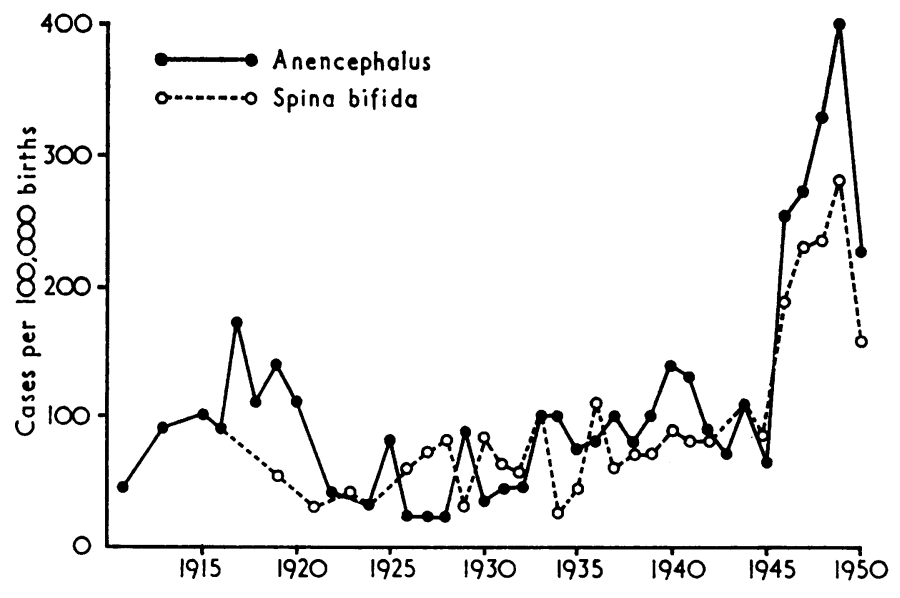

Fig. 12. Prevalence of anencephaly and spina bifida among hospital births in Berlin and en- virons, 1911-50. After Gesenius (1952).

the rest of the British Isles (Fig. 11). Potato harvests were good during the war so there was little shortage (except in 1940-41 due to the loss of the Channel Islands and their early crops). Blemished tubers could therefore be discarded, the more so as they would not be suitable for boiling in their skins-a custom much encouraged during the war. At this late date it may not be possible to achieve a definitive interpretation of ASB incidences in the war years, when so many factors were changed. However, those solanines that are found in abundance in the skin of healthy tubers and which must therefore have been consumed in quantity during the war are shown by the lack of a war-time epidemic of ASB to be unlikely as contenders for the oral teratogenic role. The evidence points rather to a teratogen that is present preponderantly in diseased or damaged tubers. It may or may not be a member of the steroid alkaloid group of compounds.

There was a brief but dramatic epidemic of ASB in Berlin and Leipzig in the post-war years, 194650 (see Fig. 12 and Gesenius, 1952; Canzler et al., 1969). Normally, more than half of Germany's potatoes are for animal fodder or industry. The varieties so used (Ackersegen being the predominant one) contain high concentrations of solanines (Lepper, 1949). It seems possible that, in the postwar famine, many of these potatoes reached human consumption and were in poor condition when they did so. On the present hypothesis, the imperfect ones contributed to the ASB epidemic. Conditions in parts of Naples were not much better at that time and Candido's high figure of 4 anencephalics per 1,000 hospital births in 1943-1951 (Böök and Fraccaro, 1956) perhaps reflects an epidemic comparable to that in Berlin.

No other epidemic of these magnitudes has yet been described in any part of the world, but, in nearly all high-frequency areas, there are marked음 year by year variations in incidence. It would be important to relate these to the severity of blight 3 which varies markedly from year to year because of weather and other factors. The summarized $\overrightarrow{0}$ annual figures are usually imperfect for this purpose $N$ because the majority of blight records concern the date of $75 \%$ destruction of the haulm which is ond an imperfect indicator of the percentage of tubers that are blighted. More importantly, since the peak of ASB incidence is near the year-end in the nor- $\frac{}{D}$ thern hemisphere, a high peak will be partly reflected in both the old and the new year. The usualo를 yearly anencephaly figures thus include the tail of one winter's peak (January-April) and the long lead up to the next winter's peak and often the peak itself (September-December). On the present $\Phi_{\odot}$ hypothesis, these two parts relate to the potato-? growing conditions of separate years. If we take 3 into account all factors, the effect of a blight year on anencephaly numbers will be evident mainly in the births of the following year with a variable degree of overlap into the year after that. For spina bifida, with a seven-week longer gestation $>$ time (normal), the effect will be more marked in the later year (two years after the blight attack). N

Record (1961) gives the incidence for anencephaly in Scotland according to the year in which the malformation was initiated. Cox and Large (1960, $\omega$ Table 21) give blight severity (moderate, slight, negligible) for part of the same period. There is a good correlation between the blight score for west $\Phi_{\infty}^{\infty}$ Scotland (where most of the births occur) and the incidence of anencephaly that was initiated among ${ }_{0}^{-}$ infants in Scotland in the following year (Fig. 13). $\frac{\mathrm{D}}{\mathrm{D}}$ Partly blighted potatoes, with consequently high $\frac{\rho}{\mathrm{D}}$ 


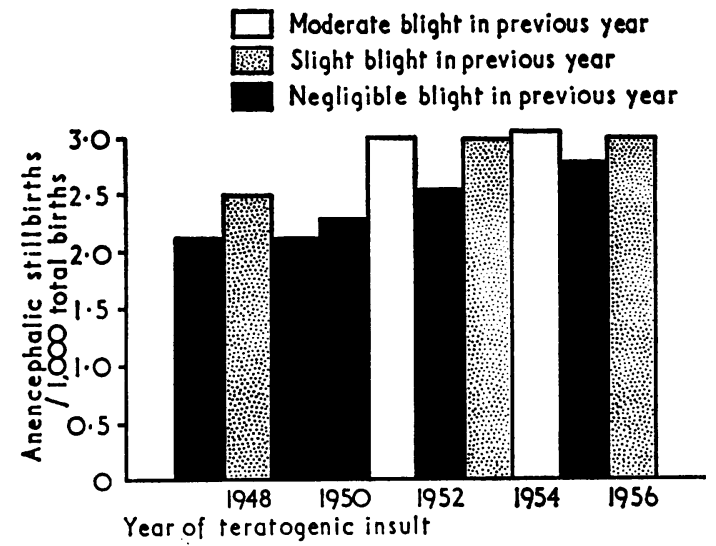

FIG. 13. Incidence of anencephalic stillbirths per 1,000 total births in Scotland, according to year of presumed teratogenic insult (SE $0.15-0.18$ per 1,000 ). This correlates well with the severity of blight in the preceding year. Blight has been scored for the most populous region-the west-in three grades, moderate, slight, and negligible, After Fig. 7 of Record (1961). Mean after moderate blight 3.0; slight. $2 \cdot 8$; negligible $2 \cdot 4$ per 1,000 .

fungitoxic levels (Locci and Kuć, 1967), are the most likely agents of this correlation. The month of peak teratogen consumption following blight will tend to be unpredictable because, although the proportion of tubers that are blighted will decline through the winter due to their poor keeping qualities, the concentration of teratogen in all tubers will increase with time in storage.

Moss (1964) gives the number of anencephaly births by year of conception for Leicester, England and notes peaks in 1955 and 1957. As illustrated in Fig. 14, both peaks occurred one year after a blight year had been officially so designated in the nearby potato-growing Fens. The dip between the peaks followed a non-blight year, 1955. The decline in incidence of ASB since 1957 in that study hopefully reflects the success of a vigorous spraying programme, nearly $80 \%$ of crops in the Fens being sprayed by 1961 . The year 1960 was a blight year (for unsprayed crops) but, despite this, there was a slight fall in ASB incidence in 1961 conceptions so the correlation is not complete. Perhaps spraying had controlled the tuber infection rate: certainly, the infection of the tubers can be very variable even from field to field.

Other hints that a year-to-year variation reflects blight attack are found in the data of several papers but interpretation is more uncertain because the

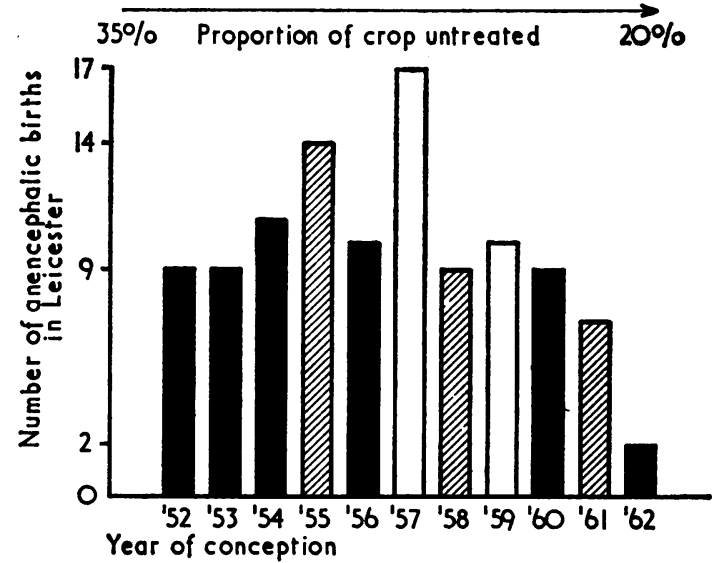

Severe blight on unsprayed crop in previous year Mean no. anencephalic births 13.5, SE 2.6 $\equiv$ Moderate blight on unsprayed crop in previous year

Mean no, anencephalic births $10.3, \mathrm{SE} 1.6$ Slight blight on unsprayed crop in previous year

Mean no. anencephalic births $7 \cdot 8$, SE $1 \cdot 3$

FIG. 14. Numbers of anencephalic births (live and still) in Leicesterd 1952-62, by year of conception. Severity of blight on unspraye potato crop in year preceding conception in near-by Fen district is also indicated and there is some correlation. The correlation is part obscured by the downward trend in all three categories of ye ar (severe, moderate, and slight blight) but it shows clearly in the me an numbers of anencephalic births, $13.5,10 \cdot 3,7.8$, in these three categories respectively. The trend in anencephaly numbers, with little change in total number of births, perhaps refiects the efficacy of the anti-blieht spraying which increased from about $65 \%$ to about $80 \%$ over this period. Data of Moss (1964) and Cox and Large (1960), supplemented by Dr. F. J. Moore.

data are given by year of ASB birth rather than year of conception or of teratogenic insult. The ASB birth may be either one or, particularly for spina bifida, two years after the blight attack. The paper of Ward and Irvine (1961) gives data on anencephalic still-births in the city of Exeter. Many of these should fall in the same year as the teratogen was effective, i.e., one year after the blight attack. There is a good fit to this expectation. The blight data were made available to me by Dr. F. J. Moore of the Plant Pathology Laboratory of the Ministry of Agriculture, Fisheries and Food, Harpenden, U.K. (see foot of page).

\section{Sex Ratio}

In all ASB data, there is a marked excess of females (the male: female sex ratio is $1: 2.3$ for anencephaly and 1:1.2 for spina bifida cystica) (MacMahon, Pugh, and Ingalls, 1953). The disparity between the sexes is more marked in younger

\begin{tabular}{|c|c|c|c|c|c|c|c|c|}
\hline Year of stillbirth in Exeter: Ward, Irvine (1961) & 1954 & 1955 & 1956 & 1957 & 1958 & 1959 & 1960 & Total \\
\hline $\begin{array}{l}\text { No. of anencephalic stillbirths } \\
\text { Blight severe in year previous to birth }\end{array}$ & $\begin{array}{c}8 \\
\text { Yes }\end{array}$ & $\begin{array}{c}6 \\
\text { Yes }\end{array}$ & $\begin{array}{c}0 \\
\text { No }\end{array}$ & $\begin{array}{c}3 \\
\text { Yes }\end{array}$ & $\begin{array}{c}4 \\
Y \text { es }\end{array}$ & $\begin{array}{c}4 \\
Y e s\end{array}$ & $\begin{array}{c}0 \\
\text { No }\end{array}$ & 25 \\
\hline
\end{tabular}


mothers (MacMahon and McKeown, 1952). There are apparently geographical variations in it, too (Stocks, 1970), the sex disparity appearing greatest in regions of high incidence.

Mittwoch, Delhanty, and Beck (1969) have demonstrated a sex differential in the rate of development of mammalian embryos even in early stages, at least in the gonads. It is, therefore, not too difficult to conceive of an excess in females in the duration of a window of susceptibility to some teratogen. Further, this excess could be greater for anencephaly than for spina bifida, thus permitting differences in the sex ratio in the two conditions (Hay, 1970). Sex-ratio data need not, therefore, offer a stumbling block to the present group of hypotheses. But we are so far from understanding them that they are unlikely to assist in the identification of the teratogenic agent.

\section{SOFTNESS OF WATER}

A correlation has been claimed in the United Kingdom between softness of regional water supplies and the regional ASB incidence (Fedrick, 1970b; Lowe, Roberts, and Lloyd, 1971). There is also a correlation in the United Kingdom between water softness and rainfall (geological factors having a major influence on both), so the soft water effect may, therefore, be only a very indirect one through successive intermediate stages of geology, rainfall, and potato pathology. Moreover, within Glasgow. supplied from a single soft-water source, there are large variations in ASB incidence in different areas of the city (Wilson, 1971). Fielding and Smithells (1971) also refute the generality of the association: Liverpool has softer water than two neighbouring towns but has lower ASB rates. Further, the artificial softening of St. Helens water seems to have had no influence on ASB rates.

\section{COMMENT}

So far, the available data can all be reconciled in a general way with a role for blight in the pathogenesis of ASB. In particular, correlations have been demonstrated in geographical distributions and year-to-year secular distributions of incidences. The potato is clearly an intermediate agent between blight and ASB and it introduces variations such as those in per capita consumption by nation, region, class, race, year, and season. The plant-breeder has introduced, through new potato varieties, the variables of blight-resistance and inducibility of phytoalexins. The farmer has introduced the variables of early, mid-season, and late cropping, and of divergent anti-blight measures. The general course of history has determined the spread of the fungus, most recently to Chile, for example, and has deter- $\mathcal{C}$ mined the human migrations, wars, famines, and food customs. The weather has dominated all $\frac{3}{0}$ components-fungus, potato, and man-through ? alternating clemency and inclemency. It is hardly $\overrightarrow{\vec{s}}$ surprising that several writers have despaired of $\frac{\rho}{\circ}$ finding a final common path for all these influences, when only one indicator is available for studythe incidence of ASB.

Even now, though the potato carries the mark of $\cong$ all these influences imprinted on its size, number, क and chemical constitution, the route by which it $\overrightarrow{0}$ transmits this mark to the expectant motherthe next part of the aetiological pathway-is still, to some extent, in doubt.

\section{Route of Access of the Teratogen}

\section{Percutaneous Route}

So far, some evidence has been given in terms of the percutaneous route for the teratogen. Such a 윽 route comes near to explaining the lack of wartime epidemics (Figs. 11 and 12) in Britain (MacMahon, $z$ Record, and McKeown, 1951) or Germany (Gesenius, 1952) because the reduction of household size $\vec{\varphi}$ and the reduction in the proportion of potatoes thes were peeled compensated to a large extent for the increase in potato consumption per head and lefif the scale of the potato-peeling for the expectant mother relatively unchanged. It also provides a coherent explanation for the complex maternal $\frac{\otimes}{\varnothing}$ age and parity effects and their variability from place to place. Again the explanation is in terms of the aggregate household appetite for potatoes and the consequent degree of exposure of the expectant mother's hands to potato peel (or to the peeled potato, or to the water in which the unpeeled potatoes are immersed). Some steroids are slowly absorbed through the intact human skin (Rook, Wilkinson and Ebling, 1968). One of the steroid alkaloids-even $\alpha$-solanine or $\alpha$-chaconine-could fit most of the data if it is absorbable by this route.

A prediction appropriate to the percutaneous route would be, however, that there would be an $>$ extra hazard to those women who, in season, pick potatoes in the field and to those women who work $N_{\circ}$ in the declining occupation of potato-peeling for restaurants and hotels which is now increasingly $N$ relegated to machines. McDonald (1958) found that $\underset{\omega}{ }$ the work of only one of the 16 mothers of ASB infants was in a canteen (and did not necessarily involve potato-peeling). Record and Mckeown $\Phi$ (1949) also found no excess of women in such occu- $\stackrel{?}{?}$ pations. Perhaps there are relevant ways in which $\frac{T}{T}$ the commercial operation of potato-peeling differed $\frac{\vec{D}}{\mathrm{D}}$ from the domestic, even before machine-peeling $\frac{}{\mathbb{Q}}$ 
became the rule, but I am assured that gloves are too little worn to explain the lack of major occupational hazard. There are several precedents for occupational hazards to be missed but, despite this, the absence of any known scientific report or even folk-lore on the hazard, before the arrival of peeling machines, undoubtedly counts against the percutaneous route and compels us to consider other routes.

\section{INHALATION ROUTE}

The route by inhalation may be briefly considered. The scraping of potatoes produces a spray and some of the droplets, small enough to constitute an aerosol, no doubt reach the lung so that any toxins dissolved in them have an opportunity to be absorbed. This route provides a mechanism for the risk to be proportional to the aggregate household appetite and therefore explains the age and parity effects and the lack of wartime epidemics. The latter is further explained in terms of the custom of eating potatoes in their jackets that was encouraged during the war. The operation of scraping would be thereby diminished. A small survey of mothers of ASB offspring is planned to compare their predilections for scraping with those of a control group. This would allow an assessment of this route but it is not expected that the assessment will be favourable. (See Addendum.)

\section{Oral Route}

At first sight, the risk from the ingestion of a teratogen in potatoes would be expected to be dependent mainly on the appetite of the individual for potatoes but, under certain conditions, the risk for the housewife mother could be dependent instead upon the aggregate appetite of the household as is required here. One necessary condition would be that the teratogen be present in quantity in only a minority of tubers so that the chance of any particular boiling containing at least one such tuber would be roughly proportional to the number of tubers in the boiling. It would further be necessary for the teratogen of that tuber to be shared among the members of the household and for that share to be sufficient to initiate the malformation in a manner dependent merely on timing factors and (within limits) not on dose. The mashing of potatoes is common in this country for old potatoes and provides the required sharing mechanism. An adequate sharing of the teratogen could also occur when the potatoes are eaten unmashed, provided that the solubility and other properties of the teratogen are such as to permit its diffusion through all the tubers in the pan during boiling. None of these conditions for the oral route to generate a risk proportional to household appetite seems to be unduly restrictive. If it is the true route, the complex age and parity effects, the class effect, and the lack of major wartime epidemics (Figs. 11 and 12) can therefore be adequately accommodated. In fact, since no occupational hazard is expected, the route fits all the known data, by arguments similar to those deployed in discussing the percutaneous route in the earlier parts of this paper.

The hypothesis may now be stated fairly precisely: that we may in principle prevent the great majority of occurrences of anencephaly and spina bifida cystica (among other unspecified conditions) by denying access of potato teratogen to the potentially pregnant woman. The teratogen is believed to be in above-average concentration in certain varieties of potato, particularly in overwintered tubers that are partially blighted or injured. The route by which the teratogen is absorbed is not yet known, nor is its chemical nature. The route by ingestion is the most likely one at the moment and, if so, the teratogen, probably a phytoalexin, may be a steroid alkaloid but one that occurs in few tubers (unlike $\alpha$-solanine and $\alpha$-chaconine which are more pervasive than this). It may, however, be rishitin or phytuberin or an unknown compound. Whatever it is must be largely resistant to boilinga deduction applicable to this route only.

\section{TESTING THE HyPOTHESIS}

As mentioned in the introduction, the marmoset embryo is now known to be a practical analogue of the human embryo. For the first time in this problem, we can therefore begin to envisage a transition from epidemiology through excogitation to experimentation and eventual exploitation.

A proportion of the information used above will no doubt prove to be misleading. Further, retrieval of information from the literature, though more extensive than the reference list might imply, is certainly not complete. Nevertheless, perhaps the argument that has been built up is sufficient to justify some reasonable preventive tests in man and experiments with marmosets. Some of the latter are now in progress at the hands of Professor D. E. Poswillo. It will probably be necessary later to transfer most of the work to a smaller mammal for chemical identification of the teratogen.

\section{INTERIM MEASURES}

Until the route is more definitely established, a detailed discussion of preventive measures would be premature. Certain points seem, however, to be worth a mention even at this early stage. 
It would seem appropriate for anti-blight measures to be intensified yet further, the more so because they seem already to have demonstrated their efficacy in reducing ASB incidences in recent years, in Leicester, for example (Moss, 1964).

Regulations already restrict the sale for human consumption of blemished potatoes. Perhaps their efficacy could be reviewed as it is common experience that many imperfect tubers do reach the market. Tuber damage during harvesting could presumably be reduced by slower tractor speeds.

Potentially pregnant women, as well as taking care to discard imperfect tubers, might further reduce the small risk of an ASB malformation by boiling their own potatoes in a small pan separately from those of the rest of the household. Those women who have undue risk from having already borne such a child could, of course, reduce that risk to any desired figure by reducing their exposure to potatoes to the appropriate extent.

\section{Futher CONSIDERATIONS}

The problem of prevention of ASB has taken on a new urgency in the present decade since it became possible through surgery to keep alive, at least for a time, about $80 \%$ of babies born alive with spina bifida cystica, although perhaps not more than $36 \%$ are still alive at age 3 (Lorber, 1968). Even if selection for surgery is restricted to non-paralysed patients, only a proportion will lead a normal life (Knox, 1967), the others being educationally subnormal, unable to walk or incontinent (Wilson, 1970), so the ethical problems posed to the paediatrician by the option of surgery are onerous indeed. Prevention is clearly the best way of tackling this problem. Anencephaly is, by comparison, a small burden to the community and to the family but it should respond to the same preventive action.

The ASB effect on viable fetuses is only a fraction of the total fetal damage from this presumed teratogen. Nishimura et al. (1966) found a severalfold higher incidence of ASB among the products of induced abortion than at term. Further, some malformations recorded as hydrocephaly are likely to have the same or similar origin, for the hydrocephaly class as a whole shares many epidemiological features with ASB. Edwards (1961) noted a seasonal peak incidence in December for exomphalos and, although he did not claim formal significance for this effect, he remarked cogently on the co-existence of this abnormality with ASB (Coffey and Jessop, 1957; see also Smithells, Chinn, and Franklin, 1964; Smithells and Chinn, 1965). Even if the seasonal effect had been definitely established for exomphalos, it would not be easy to decide whether 0 to propose that exomphalos results from a different teratogen from the same source or to propose that it $\bar{D}$ reflects a divergent effect of the one chemical $\stackrel{\circ}{-}$ agent. If the latter were to be favoured, the difference $\overrightarrow{\vec{F}}$ in outcome would presumably be attributed to a $\frac{7}{0}$ difference of timing or dose or other incidental $\frac{\mathrm{O}}{\mathrm{C}}$ circumstance.

Indeed, the same question exists even for the two abnormalities that have been lumped together, for convenience, as ASB. Sibship and co-twin data and ${ }_{-}^{\infty}$ data on the frequency of co-existence of anencephaly. and spina bifida cystica (Böök and Rayner, 1950) $\vec{\omega}$ in various circumstances might all be relevant in $\stackrel{\omega}{\circ}$ discriminating between the one and two teratogen $\vec{\Phi}$ alternatives. At present there is no obvious need? to postulate more than one but discussion of this would not be appropriate here. As with thalidomide, ? it may be that even as small a dose as $16 \mathrm{mg} / \mathrm{kg}$ of a single teratogen might be $100 \%$ effective when음 given at the right time (Barrow, Steffek and King,1969).

In the light of the finding by Stocks (1970) of high correlations in geographical space between $\vec{\theta}$ ASB incidence and the mortality from variobs $N$ adult diseases, particularly cardiovascular diseases, it is suggested that the same potato toxin orôa related one requires study on a broad front. Stocks found no correlation between adult disease andD any other group of malformations.

\section{SUMMARY}

A correlation in geographical space has been found in published material between the average severity of late-blight (Phytophthora infestans). attack of potatoes and the incidence of anencephaly and spina bifida cystica in man. A correlation is also found between the incidence of these malfor- -3 mations and the blight severity in the year prior to that in which the teratogenic insult occurs. Other epidemiological data suggest that these correlations reflect a teratogenic action of a substance in potator tubers that has a much-above-average concentra $\frac{D}{8}$ tion in a minority of tubers, particularly blightedE. ones from certain potato varieties after winterf storage. Absorption of teratogen is probably, but not certainly, from ingestion. If the proportion of rogue tubers is small, the risk would be roughlye proportional to the number of potatoes in the pare and therefore proportional to the aggregate appetite of the members of the household. This would be in accord with the influences of age and parity.

I thank the library staffs at the London School of Hygiene and Tropical Medicine and elsewhere for thei skilled assistance. 


\section{REFERENCES}

ABou-DAoud, K. T. (1966). Congenital malformations observed in 12,146 births at the American University Hospital in Beirut. J. méd. Liban., 19, 113.

Allen, E. H. (1970). The nature of antifungal substances in the peel of Irish potato tubers. Phytopathol. Z., 69, 151.

- , and FrLdmesSer, J. (1971). Nematicidal activity of $\alpha$-chaconine: effect of hydrogen-ion concentration. J. Nematol., 3, 58.

- , and Kuć, J. (1968). $\alpha$-solanine and $\alpha$-chaconine as fungitoxic compounds in extracts of Irish potato tubers. Phytopathology, 58, 776.

Alter, M. (1962). Anencephalus, hydrocephalus and spina bifida. Arch. Neurol. (Chic.), 7, 411.

Anderson, W. J. R., Baird, D., and Thomson, A. M. (1958). Epidemiology of stillbirths and infant deaths due to congenital malformation. Lancet, 1, 1304.

Austin, D. J., and Clarke, D. D. (1966). Production of coumarins by Phytophthora infestans. Nature (Lond.), 210, 1165.

Barrow, M. V., Steffek, A. J., and KING, C. T. G. (1969). Thalidomide syndrome in Rhesus monkeys. Folia primatol., 10, 195.

BarRus, M. F., BoYD, O. C., and Wood, J. I. (1931). Diseases of plants in the United States in 1930. Plant Dis. Rep., Suppl., 81, 91.

de Bellefeuille, P. (1969). Contribution à l'étiologie de l'anencéphalie par l'étude des jumeaux. Un. méd. Cans., 98, 437.

Beolchini, P. E., and Bailo, U. (1965). Sull'esistenza di variazioni stagionali della frequenza dell'anencefalia. Minerva ginec., 17, 928.

BöMER, A., and MATTIS, H. (1924). Der Solaningehalt der Kartoffeln. Z. Untersuch. Nahr.-u. Genussmitt., 47, 97.

BööK, J. A., and Fraccaro, M. (1956). Research on congenital malformations. Etud. néo-natal., 5, 39.

-, and RAYNER, S. (1950). A clinical and genetical study of anencephaly. Amer. J. hum. Genet., 2, 61.

Burton, W. G. (1966). The Potato, 2nd ed. Veenman, Wageningen, Holland.

Butler, N. R., and Alberman, E. D. (1969). eds. Perinatal Problems: The Second report of the 1958 British Perinatal Mortality Survey. Livingstone, Edinburgh and London.

Canzler, E., Funk, G., and Schlegel, L. (1969). Die Missbildungshäufigkeit an der Universitäts Frauenklinik Leipzig in den Jahren 1941 bis 1965. Zbl. Gynäk., 91, 833.

Carter, C. O., Laurence, K. M., and David, P. A. (1966). The genetics of the major central nervous system malformations, based on the South Wales sociogenetic investigation. Develop. Med. Child Neurol., 9, Suppl. 13, 30.

- and ROBERTS, J. A. F. (1967). The risk of recurrence after two children with central-nervous-system malformations. Lancet, 1, 306.

CASSADY, G. (1969). Anencephaly: a 6-year study of 367 cases. Amer. J. Obstet. Gynec., 103, 1154.
Chor, N. W., and Peters, E. L. (1969). On the epidemiology of neural-tube defects with particular reference to temporal-spatial distributions. Neurology, 19, 290. (abstr).

Christie, R. J. (1969). An occurrence of monozygotic twinning and anencephaly in Macaca arctoides. Lab. Anim. Care, 19, 531.

Clarke, D. D. (1972). The resistance of potato tissue to the hyphal growth of fungal pathogens. Proc. Roy. Soc. (B.). (In press).

CofFeY, V. P., and JEsSOP, W. J. E. (1957). A study of 137 cases of anencephaly. Brit. J. prev. soc. Med., $11,174$.

Collmann, R. D., and Stoller, A. (1962). Epidemiology of congenital anomalies of the central nervous system with special reference to patterns in the state of Victoria, Australia. J. ment. Defic. Res., 6, 22.

Cox, A. E., and LARge, E. C. (1960). Potato Blight Epidemics throughout the World, Agriculture Handbook No. 174. U.S. Department of Agriculture, Agricultural Research Service, Washington.

CrUZ-Coke, R. (1970). Birth control and sex-ratio. Lancet, 2, 426.

Czeizel, A., and Révész, C. (1970). Major malformations of the central nervous system in Hungary. Brit. J. prev. soc. Med., 24, 205.

Damyanov, I., and Dutz, W. (1971). Anencephaly in Shiraz, Iran. Lancet, 1, 82.

Davidson, W. D. (1937). Potato Growing for Seed Purposes. Dublin Stationery Office, Dublin.

DunN, K. G., and Salter, J. C. (1944). Recurrent anencephaly. J. Obstet. Gynaec. Brit. Emp., 51, 529.

EDWARDS, J. H. (1958). Congenital malformations of the central nervous system in Scotland. Brit. J. prev. soc. Med., 12, 115.

(1961). Seasonal incidence of congenital disease in Birmingham. Ann. hum. Genet., 25, 89.

Elwood, J. H. (1970a). Anencephalus in Belfast: incidence and secular and seasonal variations, 1950-66. Brit. J. prev. soc. Med., 24, 78.

(1970b). Anencephalus in the British Isles. Develop. Med. Child Neurol., 12, 582.

$\longrightarrow$, and MACKENZIE, G. (1971). Comparisons of secular and seasonal variations in the incidence of anencephalus in Belfast and four Scottish cities, 1956-66. Brit. J. prev. soc. Med., $25,17$.

ERHARDT, C. L., and Nelson, F. G. (1964). Reported congenital malformations in New York City, 195859. Amer. J. publ. Hlth, 54, 1489.

FEDRICK, J. (1970a). Anencephalus: variation with maternal age, parity, social class and region in England, Scotland and Wales. Ann. hum. Genet., 34, 31.

(1970b). Anencephalus and the local water supply. Nature (Lond.), 227, 176.

Fielding, D. W., and Smithells, R. W. (1971). Anen cephalus and water hardness in South-West Lancashire Brit. J. prev. soc. Med., 25, 217.

Fogel, B. J., Nitowsky, H. M., and Gruenwald, P. (1965). Discordant abnormalities in monozygotic twins. J. Pediat., 66, 64. 
Fraser, F. C., Fainstat, T., and Kalter, H. (1953). The experimental production of congenital defects with particular reference to cleft palate. Etud. néonatal., $2,43$.

Frézal, J., Kelley, J., Guillemot, M. L., and lamy, M. (1964). Anencephaly in France. Amer. J. hum. Genet., 16, 336.

Gesenius, H. (1952). The increase of births of monsters in Berlin and its suburbs in the post-war years. Int. J. Sexol., 6, 24.

Giroud, A. (1960). Causes and morphogenesis of anencephaly. In: Ciba Foundation Symposium on Congenital Malformations., pp. 199-218. Edited by G. E. W. Wolstenholme and C. M. O’Connor. Churchill, London.

Gitrelsohn, A. M., and Milham, S. (1962). Declining incidence of central nervous system anomalies in New York State. Brit. J. prev. soc. Med., 16, 153.

_- (1965). Vital record incidence of congenital malformations in New York State. In: Genetics and the Epidemiology of Chronic Diseases, edited by J. V. Neel, M. W. Shaw, W. J. Schull. pp. 305-319. U.S.P.H.S., Washington.

GreEN, C. R. (1964). The frequency of maldevelopment in man. Amer. J. Obstet. Gynec., 90, 994.

Gull, D. D., and IsEnBERG, F. M. (1960). Chlorophyll and solanine content and distribution in four varieties of potato tubers. Proc. Amer. Soc. horti. Sci., 75, 545.

GUTHKELCH, A. N. (1962). Studies in spina bifida cystica: III Seasonal variation in the frequency of spina bifida births. Brit. J. prev. soc. Med., 16, 159.

HaleVI, H. S. (1967). Congenital malformations in Israel. Brit. J. prev. soc. Med., 21, 66.

HAY, S. (1970). Sex differences in the incidence of certain congenital malformations: a review of the literature and some new data. Teratology, 4, 277.

HewitT, D. (1963). Geographical variations in the mortality attributed to spina bifida and other congenital malformations. Brit. J. prev. soc. Med., 17, 13.

(1965). Regional variations in the incidence of spina bifida. In Genetics and the Epidemiology of Chronic Disease, p. 295-303, edited by J. V. Neel, M. W. Shaw and W. J. Schull. U.S.P.H.S., Washington.

HORNE, H. W. (1958). Anencephaly in four consecutive pregnancies. Fertil. \& Steril., 9, 67-68.

Horowitz, I., and McDonald, A. D. (1969). Anencephaly and spina bifida in the Province of Quebec. Canad. med. Ass. J., 100, 748.

HowIE, R. N., and Phillips, L. I. (1970). Congenital malformations in the newborn: a survey at the National Women's Hospital 1964-67. N.Z. med. J., 71, 65.

InGALls, T. H., and KlingBerg, M. A. (1965). Congenital malformations: clinical and community considerations. Amer. J. med. Sci., 249, 316.

JONES, W. R. (1967). Anencephalus: a 23-year survey in a Sydney hospital. Med. J. Aust., 1, 104.

KälLÉN, B., and WinBerg, J. (1968). A Swedish register of congenital malformations. Pediatrics, 41, 765.

Katsui, N., Murai, A., Takasugi, M., Imaizumi, K., and MASAMUNE, T. (1968). The structure of rishitin, a new antifungal compound from diseased potato tubers. Chem. Comm., p. 43.
KeELER, R. F. (1969). Toxic and teratogenic alkaloidso of Western range plants. J. Agr. Food Chem., 17, 473.

- (1971). Teratogenic compounds of Veratrunt? californicum (Durand) XI. Gestational chronology and compound specificity in rabbits. Proc. Soc. exper.? Biol. Med., 136, 1174.

KLINE, B. E., von Elbe, H., Dahle, N. A., and KuPChan, 을 S. M. (1961). Toxic effects of potato sprouts and of solanine fed to pregnant rats. Proc. Soc. exp. Biol. (N.Y.), $107,807$.

KNox, G. (1967). Spina bifida in Birmingham. Develop. Med. Child Neurol., 9, Suppl. 13, 14-22.

Kolah, P. J., Master, P. A., and SAnghvi, L. D. (1967). Congenital malformations and perinatale

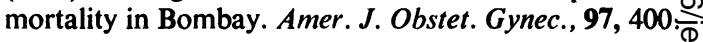

KuYPERS, H. M., and HuisJes, H. J. (1971). Anencefalie. Ned. T. Geneesk., 115, 1075.

KuČERA, J. (1965). Die Erfassung der angeborenen Missbildungen in der CSSR. Ann. Pediat., 204, 141.

LAURENCE, K. M. (1969). The recurrence risk in spina bifida cystica and anencephaly. Develop. Med. Chilcb Neurol., Suppl. 20, 23.

-, Carter, C. O., and David, P. A. (1968). Major central nervous system malformations in South Wales. Brit. J. prev. soc. Med., 22, 146 and 212.

LECK, I. (1966). Changes in the incidence of neural-tubies defects. Lancet, $2,791$.

- (1969). Ethnic differences in the incidence of malformations following migration. Brit. J. prev. soc. Met? 23, 166-173.

-, and RECORD, R. G. (unpublished).

, and - (1966). Seasonal incidence of anence-ब phalus. Brit. J. prev. soc. Med., 20, 67.

$\longrightarrow$, and Rogers, S. C. (1967). Changes in the incidenceô of anencephalus. Brit. J. prev. soc. Med., 21, 177.

LEPPER, W. (1949). Solaningehalte von 58 Kartoffelsorten Z. Lebensmitt.-Untersuch., 89, 264.

LE VANN, L. J. (1963). Congenital abnormalities in children born in Alberta during 1961: a survey and aᄋ hypothesis. Canad. med. Ass. J., 89, 120.

LILJEMARK, A., and WidOFF, E. (1960). Greening and solanine development of white potato in fluorescento light. Amer. Potato J., 37, 379.

LocCI, R., and Kuć, J. (1967). Steroid alkaloids as compounds produced by potato tubers under stress. $\bigcirc$ Phytopathology, 57, 1272.

LORBER, J. (1965). The family history of spina bifida을 cystica. Pediatrics, 35, 589.

(1968). The problem of spina bifida. Med. Offr. 119, 213.

LOWE, C. R., RoberTS, C. J., and Lloyd, S. (1971).N Malformations of central nervous system and softness $\mathrm{\omega}^{\mathrm{\omega}}$ of local water supplies. Brit. med. J., 2, 357.

MCDonald, A. D. (1958). Maternal health and congeniso tal defect. New Engl. J. Med., 258, 767.

MCKEE, R. K. (1955). Host parasite relationships in the $?$ dry rot disease of potatoes. Ann. appl. Biol., 43, 147.

MCKeOWN, T., and ReCORD, R. G. (1951). Seasonalö incidence of congenital malformations of the centralo nervous system. Lancet, 1, 192. 
MacMahon, B., and McKeown, T. (1952). A note on the sex ratio in anencephalus. Brit. J. soc. Med., 6, 265.

—, Pugh, T. F., and Ingalls, T. H. (1953). Anencephalus, spina bifida, and hydrocephalus incidence related to sex, race, and season of birth, and incidence in siblings. Brit. J. prev. soc. Med., 7, 211.

—, Record, R. G., and McKeown, T. (1951). Secular changes in the incidence of malformations of the central nervous system. Brit. J. soc. Med., 5, 254.

$\longrightarrow$, and YEN, S. (1971). Unrecognised epidemic of anencephaly and spina bifida. Lancet, $1,31$.

MaLL, F. P. (1917). On the frequency of localized anomalies in human embryos and infants at birth. Amer. J. Anat., 22, 49.

Martin, A. J. P. (unpublished).

MINISTRY OF AGRICULTURE, FISHERIES AND FoOD (1957). Ann. Rep. Nat. Food Survey Cttee. Domestic Food Consumption and Expenditure, 1955. H.M.S.O., London.

- (1969). Ann. Rep. Nat. Food Survey Cttee. Household Food Consumption and Expenditure, 1967. H.M.S.O., London.

MINISTRY OF FooD (1951). First Rep. Nat. Food Survey Cttee. The Urban Working-class Household Diet, 1940 to 1949. H.M.S.O., London.

Mittwoch, U., Delhanty, J. D. A., and BeCK, F. (1969). Growth of differentiating testes and ovaries. Nature (Lond.), 224, 1323.

Morton, N. E., Chung, C. S., and Mi, M. P. (1967). Genetics of inter-racial crosses in Hawaii. Monographs in Human Genetics, vol. 3, edited by L. Beckman and M. Hauge. Karger, Basel.

Moss, B. J. L. (1964). Congenital abnormalities in Leicester, 1953-62. Med. Offr., 112, 79.

MufarRiJ, I. K., and Kilesian, V. O. (1963). Anencephaly: an analysis of anencephalic births and a report of a case of repeated anencephaly. Obstet. and Gynec. $22,657$.

NAGGAN, L. (1969). The recent decline in prevalence of anencephaly and spina bifida. Amer. J. Epidem., 89, 154.

- (1971). Anencephaly and spina bifida in Israel. Pediatrics, 47, 577.

$\longrightarrow$, and MacMahon, B. (1967). Ethnic differences in the prevalence of anencephaly and spina bifida in Boston, Mass., New Engl. J. Med., 277, 1119.

NeEL, J. V. (1958). A study of major congenital defects in Japanese infants. Amer. J. hum. Genet., 10, 398.

Nishie, K., GumbmanN, M. R., and Keyl, A. C. (1971). Pharmacology of solanine. Toxicol. appl. Pharmacol., 19, 81.

Nishimura, H., Takano, K., Tanimura, T. Yasuda, M., and UCHIDA, T. (1966). High incidence of several malformations in early human embryos as compared with infants. Biol. Neonat. (Basel), 10, 93.

Penrose, L. S. (1946). Familial data on 144 cases of anencephaly, spina bifida and congenital hydrocephaly. Ann. Eugen. (Lond.), 13, 73.

(1957). Genetics of anencephaly. J. ment. Defic. Res., 1, 4.
PitT, D. B., and SAmson, P. E. (1961). Congenital malformations and maternal diet. Aust. Ann. Med., 10, 268.

Pleydell, M. J. (1960). Anencephaly and other congenital abnormalities. An epidemiological study in Northamptonshire. Brit. med. J., 1, 309.

Poswillo, D. E. (1972). The marmoset as a teratological model. (In preparation.)

Price, R. A., and Gilles, F. H. (1971). Telencephalic remnants in Simian and human anencephaly. Arch. Path., 91, 529.

RECORD, R. G. (1961). Anencephalus in Scotland. Brit. J. prev. soc. Med., 15, 93.

- , and McKeown, T. (1949). Congenital malformations of the central nervous system. Brit. J. soc. Med., 3, 183.

$\longrightarrow$, and - (1950a). Congenital malformations of the central nervous system: II. Maternal reproductive history and familial incidence. Brit. J. soc. Med., 4, 26.

$\longrightarrow$, and - (1950b). Congenital malformations of the central nervous system. III. Risk of malformation in sibs of malformed individuals. Brit. J. soc. Med., 4, 217.

central nervous system: data on 69 pairs of twins. Ann. Eugen. (Lond.), 15, 285.

Richards, I. D. G. (1969). Congenital malformations and environmental influences in pregnancy. Brit. J. prev. soc. Med., 23, 218.

ROGERS, S. C., and MorRIS, M. (1971). Infant mortality from spina bifida, congenital hydrocephalus, monstrosity, and congenital diseases of the cardiovascular system in England and Wales. Ann. hum. Genet., 34, 295.

Rook, A., Wilkinson, D. S., and Ebling, F. J. G. (1968). (Eds.) Textbook of Dermatology. Oxford: Blackwell.

RüHL, R. (1951). Beitrag zur Pathologie und Toxicologie des Solanins. Arch. Pharm., 284, 67.

Sato, N., Tomiyama, K. Katsui, N. and Masamune, T. (1968). Isolation of rishitin from tubers of interspecific potato varieties containing late-blight resistance genes. Ann. Phytopath. Soc. Japan., 34, 140.

SCHREIBER, K. (1968). Steroid alkaloids: the Solanum group. In: The Alkaloids, vol. 10, p. 1, edited by $\mathbf{R}$. H. F. Manske. Academic Press, New York and London.

Schultz, A. H. (1956). The occurrence and frequency of pathological and teratological conditions and of twinning among non-human primates. Primatologia, separatum II, 965.

SeARLE, A. G. (1959). The incidence of anencephaly in a polytypic population. Ann. hum. Genet., 23, 279.

Sirotina, O. N., and SpIRINA, A. P. (1948). Poisoning by solanine in potatoes. Gig. $i$ Sanit., 13, 42.

Slater, B. C. S., Watson, G. I., and McDonald, J. C. (1964). Seasonal variation in congenital abnormalities. Preliminary report of a survey conducted by the Research Committee of Council of the College of General Practitioners. Brit. J. prev. soc. Med., 18, 1. 
Smithells, R. W., and Chinn, E. R. (1965). Spina bifida in Liverpool. Develop. Med. Child Neurol., 7, 258.

- , - and Frankin, D. (1964). Anencephaly in Liverpool. Develop. Med. Child Neurol., 6, 231-240.

-, D'ArCy, E. E., and McAllister, E. F. (1968). The outcome of pregnancies before and after the birth of infants with nervous system malformations. Develop. Med. Child Neurol., 10, Suppl. 15, 6.

Spellman, M. P. (1969). Anencephaly-a five year survey in Cork. J. Irish med. Ass., $62,316$.

SteFFerud, A. (1959) (ed.). Food: The Yearbook of Agriculture 1959. U.S. Department of Agriculture, Washington.

STERN, C. (1960). Principles of Human Genetics, 2nd ed., p. 569. Freeman, San Francisco.

Stevenson, A. C., Johnston, H. A., Stewart, M. I. P., and Golding, D. R. (1966). (Eds.) Malformations of structures developed from the neural tube (B1-B7). Chapter 4 in Congenital Malformations, Bull. World Hlth Org., 34, Suppl.

—, and WARNOCK, H. A. (1959). Observations on the results of pregnancies in women resident in Belfast. Ann. hum. Genet., 23, 382.

Srocks, P. (1970). Incidence of congenital malformations in the regions of England and Wales. Brit. J. prev. soc. Med., 24, 67.

Tomiyama, K., Sakuma, T., Ishizaka, N., Sato, N., Katsui, N., Takasugi, M., and Masamune, T. (1968). A new antifungal substance isolated from resistant potato tuber tissue infected by pathogens. Phytopathology, 58, 115.
TüNTE, W. (1968). Zur Häufigkeit angeborener Missbildungen des Zentralnervensystems and des Verdauungstraktes in den Jahren 1950-1961. Humangenetik 6, 29.

VARNS, J. L., Kuć, J., and Williams, E. B. (1971) Terpenoid accumulation as a biochemical response of the potato tuber to Phytophthora infestans. Phytopathology, 61, 174.

WARD, I. V., and IRVINE, E. D. (1961). The incidence of congenital abnormality in infants born to Exetero mothers 1954-1960. Med. Offr., 106, 381.

WeI, P. Y., and CHEN, Y. P. (1965). Congenital malformations, especially anencephalus, in Taiwan. Amer. J. Obstet. Gynec., 91, 870.

WestLUND, K. (1969). Mortality from congenital mal. formations of the central nervous system in Norway 1951-65. Brit. J. prev. soc. Med., 23, 28.

Williamson, E. M. (1965). Incidence and family aggre gation of major congenital malformation of centrap nervous system. J. med. Genet., 2, 161.

WILLIMOTT, S. G. (1933). An investigation of solanine poisoning. Analyst, 58, 431-8.

WILSON, G. S. (1959). A small outbreak of solanine poisoning. Monthly Bull. Min. Hlth, 18, 207.

Wrison, T. S., (1970). Congenital malformations of the central nervous system among Glasgow births 196468. Health Bull. (Edinb.), 28, No. 4, p. 32.

- (1971). A study of congenital malformations of fif $^{\mathrm{N}}$ central nervous system among Glasgow births 1964 68. Health Bull. (Edinb.), 29, 79.

YEN, S., and MACMAHON, B. (1968). Genetics of anencephaly and spina bifida. Lancet, $2,623$.

ZitNAK, A., and Johnston, J. R. (1970). Glycoalkaloiø̋ content of B5141/6 potatoes. Amer. Potato J., 47, 256?

\section{ADDENDUM}

Professor L. S. Penrose kindly introduced me to several women, each of whom has given birth to two or more ASB children. Two (out of nine) have hardly ever scraped a potato in their lives and none of the remainder pursued scraping beyond the time in the summer when it becomes tedious. The inhalation of microdroplets, if it contributes at all, is certainly not the only route, therefore. So far, however, the inhalation of a steam distillate containing a potential teratogen has not been ruled out. As Dr. W. E. Ormerod has reminded me, the steam distillation of relatively volatile compounds, such as rishitin, may occur during the cooking of potatoes? If the potential teratogen can be so volatilized, its inhalation by the housewife, particularly in a smal $h$. or ill-ventilated kitchen, would provide a route of absorption, without the compound's being subjecto in full to the detoxifying processes in the alimentary? tract and liver. The present epidemiological datao do not discriminate ad equately between the various possible routes. 


\section{ERRATA}

In Dr. J. H. Renwick's paper (vol. 26, p. 67) in which the preventability of anencephaly and spina bifida by potato-avoidance was suggested, the following changes and comments are required. The conclusions remain unchanged.

P.67: In the middle of the right-hand column, the reference to Schultz (1956) should have been to Wilson, J. G., and Gavan, J. A. (1967). Anatomical Record, 158, 99-110.

P.69: The first sentence of paragraph 2 contains an inversion and should read: SOLANIDINE: This steroid alkaloid, $\mathrm{C}_{27} \mathrm{H}_{43} \mathrm{NO}$, is present in the potato largely as a range of glycosides, the solanines and chaconines, toxic to fungi (Allen and Kuć, 1968; Allen, 1970), nematodes (Allen and Feldmesser, 1971), and man (Bömer and Mattis, 1924; Willimott, 1933; Sirotina and Spirina, 1948; Wilson, 1959).

P.74: In the last two lines of Table II, the incidences, $1 \cdot 6,1 \cdot 1,3 \cdot 2$, and $2 \cdot 2$, are probably underestimated because of under-reporting.

P.77: Ten lines from the foot of the page, 9 of 60 should read 9 of 69 . Consequent adjustments lead to a risk estimate of $10 \%$ for any co-twin (not $11 \%$ ) and to an ASB concordance rate estimate of $5.3 \%$ (not $5 \cdot 8 \%$ ). The Gittelsohn and Milham paper on methods was published in 1964 (not 1962). Amer. $J$. publ. Hlth, 54, 286-294.
P.78: As pointed out by Janerich, D. T. (Lancet, 1971, ii, 551), the graph from MacMahon and Yen (1971), which has been reproduced in Figure 9, refers not to two hospitals but to the Boston Lyingin Hospital only.

P.79: In the right-hand column, at the end of the first paragraph, the words 'see caption to Figure 14' should be added.

P.81: The last line should read 'Blight severe in UK in year previous to birth'.

Figure 14: The column for the year 1954 should be hatched.

'Deaths from Domestic Falls and Fractures' by T.P. Eddy (vol. 26, p. 173).

In that part of Table I (p. 178) relating to the height indices of males the proportion exceeding the 75th percentile should be 26 for Wales and Midlands and 2.4 for North; the proportion less than the 25th percentile should be 21 for Wales and Midlands and 46 for North. 